\title{
Trace Elements in Crustaceans, Mollusks and Fish in the Kenyan Part of Lake Victoria: Bioaccumulation, Bioindication and Health Risk Analysis
}

\author{
James Omondi Outa ${ }^{1,2,3} \cdot$ Chrispin O. Kowenje ${ }^{2} \cdot$ Annemariè Avenant-Oldewage $^{4} \cdot$ Franz Jirsa $^{3,4}$ (D)
}

Received: 18 October 2019 / Accepted: 23 January 2020 / Published online: 4 February 2020

(c) The Author(s) 2020

\begin{abstract}
This is the first comprehensive report on the accumulation of $\mathrm{Cr}, \mathrm{Ni}$, As, and $\mathrm{Ag}$ in the fish species Nile tilapia Oreochromis niloticus and Nile perch Lates niloticus from Lake Victoria, complemented with recent data on $\mathrm{Cu}, \mathrm{Zn}, \mathrm{Cd}$, and $\mathrm{Pb}$. This also is the first report on $\mathrm{Cr}, \mathrm{Ni}$, As, and Ag levels in invertebrates: the shrimp Caridina nilotica, gastropod Pila ovata, and bivalve Mutela bourguignati. The study was conducted at five sites in the Kenyan part of Lake Victoria: four sites in Winam Gulf influenced by various anthropogenic pressures, including a site near Kisumu City, and one in the main lake, with lesser direct anthropogenic influence. Apart from $\mathrm{Cu}$ and $\mathrm{Ag}$, which were highest in $O$. niloticus liver, the invertebrates had higher levels of trace elements than fish. Contamination of the gulf with trace elements was best mirrored by the invertebrates, whose mobility is limited; they accumulated $\mathrm{Cr}, \mathrm{Cd}, \mathrm{Ag}$, and $\mathrm{Pb}$ corresponding to the levels in the surface sediment. The accumulation of trace elements in fish species and their bioindicative potential corresponded to their habitats and feeding behaviour. The tissue contents of most trace elements were higher in the inshore-dwelling, omnivorous O. niloticus compared to the pelagic, piscivorous L. niloticus. Cu $(465 \pm 689 \mathrm{mg} / \mathrm{kg} \mathrm{dw})$ and $\mathrm{Ag}(3.45 \pm 1.49 \mathrm{mg} / \mathrm{kg} \mathrm{dw})$ in the liver of $O$. niloticus were up to 10 and 119 times higher than in L. niloticus, respectively. Oreochromis niloticus therefore has bioindicative potential for $\mathrm{Cu}$ and $\mathrm{Ag}$ contamination. Both the invertebrates and fish showed positive correlations between $\mathrm{Cu}$ and $\mathrm{Ag}$ concentrations, indicating similar source and/or uptake route. The target hazard quotients (THQ) show that there is no human health risk associated with the consumption of these fish. However, the levels of $\mathrm{Zn}, \mathrm{Cd}$, and $\mathrm{Pb}$ in $P$. ovata surpassed maximum food safety limits and are hence potentially unsafe for human consumption.
\end{abstract}

Trace elements, which include heavy metals and metalloids, occur naturally in the environment (Biney et al. 1994). Their multiple industrial, domestic, agricultural, medical, and

Electronic supplementary material The online version of this article (https://doi.org/10.1007/s00244-020-00715-0) contains supplementary material, which is available to authorized users.

Franz Jirsa

franz.jirsa@univie.ac.at

1 Department of Limnology and Bio-Oceanography, University of Vienna, Althanstrasse 14, 1090 Vienna, Austria

2 Department of Chemistry, Maseno University, P.O. Box 333, Maseno 40105, Kenya

3 Institute of Inorganic Chemistry, University of Vienna, Waehringer Strasse 42, 1090 Vienna, Austria

4 Department of Zoology, University of Johannesburg, P.O. Box 524, Auckland Park 2006, South Africa technological applications have led to their wide distribution in the environment, raising concerns over their potential effects on human health and the environment (Tchounwou et al. 2012). Trace elements pose a threat to wildlife and humans when occurring in elevated concentrations (Luczynska et al. 2018). According to the report by Pure Earth and Green Cross (2016), five of the top six global pollutants are heavy metals ( $\mathrm{Cr}, \mathrm{Cd}, \mathrm{Hg}$, and $\mathrm{Pb}$ ) and the metalloid (As), from which at least 200 million people worldwide are at risk from toxic pollution at levels above international health standards.

Aquatic ecosystems consist of several compartments, each of which has certain physicochemical properties that determine the fate of trace elements therein. In sediments, water, and biota, trace elements show different partitioning according to the properties of these elements, as well as the physicochemical and biological processes that influence their deposition, sorption, and remobilization between the sediment and the water column (Mwamburi 2013). Aquatic 
biotas are subject to the full range of chemical and physical influences of their habitat and therefore are sound indicators for the status of the respective aquatic systems (Chovanec et al. 2003). For instance, aquatic invertebrates take up and accumulate essential and nonessential trace elements from their environment through permeable body surfaces and from their diet. The result is an enormous variability in tissue and body concentrations of different elements in different taxa (Rainbow 2007). Parmar et al. (2016) noted that macroinvertebrates, such as crustaceans that live near the bottom of water bodies, have restricted mobility and therefore are powerful indicators of ecological conditions. Mollusks have been established as useful bioindicator tools, because their metal body burden often reflects the concentrations of metals in the surrounding water and sediment (Gundacker 2000; Hayes et al. 2015). Fish also have attracted much attention in the biomonitoring of surface water pollution. This reflects not only their special biological characteristics, such as relatively large body size and long-life cycle, but also the health risk to fish consumers (Zhou et al. 2008). Plessl et al. (2017) reported that fish are valuable bioindicators for evaluating trace element pollution when the life habits of the species are considered. Ecological and toxicological studies mostly use the gills, liver, kidney, and muscles tissue of fish, with muscles (edible part) being the most appropriate in terms of human health risk analysis (Luczynska et al. 2018). Aquatic biota play an important role in biomonitoring, and the main purpose of measuring trace elements concentration in this biota is to determine the toxicological threat to humans from ingesting excessive element loads in edible species (Depledge et al. 1998). The toxicity of heavy metals and metalloids has promoted various efforts around the world to set limits in food products from aquatic ecosystems. For instance, the European Union (EU) and World Health Organisation (WHO) have set maximum levels for $\mathrm{As}, \mathrm{Cd}, \mathrm{Pb}$, and $\mathrm{Hg}$ as priority substances for consumable aquatic products (EU 2008; FAO/WHO 2017). In addition, the United States Environmental Protection Agency (USEPA) has developed the target hazard quotients (THQ) formula, which is applicable in assessing the risk faced by people exposed to elements, such as $\mathrm{Cr}, \mathrm{Fe}, \mathrm{Ni}, \mathrm{Cu}$, and $\mathrm{Zn}$, through the consumption of contaminated fish (USEPA 2018a). THQ is the ratio between the potential exposure to a substance and the reference dose (level at which no adverse effects are expected) (USEPA 2018a). Nonetheless, the problem of toxic pollution remains prevalent in many low- and middle-income countries in many parts of the world (Pure Earth and Green Cross 2016).

Inland waters and freshwater biodiversity constitute a valuable natural resource in economic, cultural, aesthetic, scientific, and educational terms (Dudgeon et al. 2006). Lake Victoria, the largest lake in Africa, is the most important freshwater resource for the local population (Crul 1995), and an estimated 30 million people are dependent on the lake in one way or another. Mbabazi and Wasswa (2010) noted that industrial, agricultural, and domestic waste discharge have increased the levels of heavy metals in the lake, putting aquatic organisms and human consumers at risk. Moreover, contamination is prominent in large embayments of the lake, notably Winam Gulf (Kavirondo/Nyanza Gulf), Murchison Bay, and Mwanza Gulf, which are influenced by industrial and municipal wastes from rivers and the adjacent cities (Njuru et al. 2013; Outa et al. 2019). Various studies have investigated the levels of trace elements in the lake's surface sediments and macrophytes, e.g., Kishe-Machumu and Machiwa (2003), Ochieng et al. (2006), Mwamburi (2013), and Outa et al. (2019). In contrast, very few studies have examined the accumulation of trace elements in the fauna; most of these have focused on $\mathrm{Hg}$ and a few selected trace elements in the muscle tissue of fish. The earliest study is probably from 1987 by Wandiga and Onyari (Biney et al. 1994) on $\mathrm{Mn}, \mathrm{Fe}, \mathrm{Cu}, \mathrm{Zn}, \mathrm{Cd}$, and $\mathrm{Pb}$ in fish muscle tissue. Other studies include Campbell et al. (2003), who reported on $\mathrm{Hg}$ in the African catfish Clarias gariepinus, Nile tilapia Oreochromis niloticus, and Nile perch Lates niloticus, and Mbabazi and Wasswa (2010), who investigated the contamination of the silver cyprinid Rastrineobola argentea with $\mathrm{Cu}, \mathrm{Zn}, \mathrm{Cd}$, and $\mathrm{Pb}$. More recently, Ongeri et al. (2012) reported on the accumulation of $\mathrm{Fe}, \mathrm{Cu}, \mathrm{Zn}, \mathrm{Cd}$, and $\mathrm{Pb}$ in the muscle tissue of $O$. niloticus and L. niloticus and whole $R$. argentea samples taken between 2006 and 2007 from Winam Gulf.

This means that very scarce information is available on the bioaccumulation of other trace elements, such as $\mathrm{Ni}$ and As, and virtually no records of $\mathrm{Cr}$ and $\mathrm{Ag}$ in the fauna of the lake. Apart from Mwamburi (2013), who reported on $\mathrm{Pb}$ accumulation in the crustacean Caridina nilotica and on $\mathrm{Fe}, \mathrm{Mn}, \mathrm{Cu}$, and $\mathrm{Pb}$ in the bivalve Sphaerium sp., there are no other reported studies on trace element contents of invertebrates, which form an integral part of the aquatic food chain. In a recent study, Outa et al. (2019) reported that the surface sediment at Winam Gulf was contaminated with $\mathrm{Cr}, \mathrm{Cu}, \mathrm{Zn}, \mathrm{Ag}$, and $\mathrm{Pb}$ at levels that surpassed the consensus-based threshold effect concentrations (TEC) sediment quality guidelines outlined in Macdonald et al. (2000) and that the sediments at the inshore part of the gulf near Kisumu City were severely polluted with $\mathrm{Cu}$ and $\mathrm{Pb}$. $\mathrm{Ag}$ and $\mathrm{Pb}$ have no established biological function, whereas $\mathrm{Cr}, \mathrm{Cu}$, and $\mathrm{Zn}$ are essential but with a narrow range of concentrations between beneficial and toxic effects (Tchounwou et al. 2012). Unlike most heavy metals whose natural occurrence, anthropogenic release into the environment and toxicity have been known for decades, Ag has become a new potential pollutant in recent years (McGillicuddy et al. 2017; Plessl et al. 2019). According to WHO (2002), emissions from smelting operations as well as from the manufacture and disposal of 
certain photographic and electrical supplies were some of the anthropogenic sources of silver in the biosphere in the past. Recent studies have shown an increase in the usage of silver nano-particles in numerous consumer products, such as textiles, medical products, domestic appliances, food containers, cosmetics, paints, and nano-functionalised plastics in many parts of the world (McGillicuddy et al. 2017).

In the view of these findings, we performed a comprehensive study on the accumulation of trace elements in the lake's fauna with a link to potential health risks posed to humans who consume food products from the lake. This study targeted native invertebrate species: the decapod crustacean $C$. nilotica (Atyidae), the gastropod Pila ovata (Ampullaridae), the bivalve Mutela bourguignati (Iridinidae), and commercial fish: O. niloticus (Cichlidae) and L. niloticus (Laditae). Caridina nilotica is the only shrimp species known in Lake Victoria (Fryer 1960). Its littoral populations are epibenthic detritivores, while offshore populations may engage in facultative planktivory (Lehman et al. 1996). This shrimp is an important feed component for fish and other animals for small-scale and commercial farming in East Africa (Bundi et al. 2013; Mwamburi 2013). Mutela bourguignati is a sedentary filter feeder (Graf and Cummings 2006) and is mainly used as bait for fish. Pila ovata predominantly inhabits shallow inshore waters and feeds on a variety of items, such as biofilms, periphyton, macrophytes, other invertebrates, and carrion (Hayes et al. 2015). Like most apple snails, it has become a focus of research following its introduction to many parts of the world as a source of food protein or as aquarium pets (Hayes et al. 2015); it is regarded as an important food protein source for human populations in Congo and around Lake Victoria (Van Damme 2017). Oreochromis niloticus is an inshore fish species and an opportunistic herbivore that feeds on algae, small invertebrates, and detritus (Njiru et al. 2004). Lates niloticus juveniles are inshore dwellers and feed mainly on crustaceans and insect larvae but gradually become pelagic and piscivorous as they grow to maturity (Kitchell et al. 1997). Lates niloticus and $O$. niloticus, introduced into the lake in the 1950s, are two of the three major commercial fish species (the other being $R$. argentea) (Budeba and Cowx 2007). According to FAO (2015), despite Kenya having $142400 \mathrm{~km}^{2}$ of marine water, the inland Lake Victoria contributes approximately 75\% (approx. 139,500 tons) of Kenya's total aquatic food production. Moreover, 35\% of the lake's total fish production is landed in Kenya for internal and external markets, of which Nile perch L. niloticus accounts for $84.7 \%$ of total fish exports to Europe, Asia, United States, and Central America (FAO 2015).

In summary, this study investigated eight trace elements $(\mathrm{Cr}, \mathrm{Ni}, \mathrm{Cu}, \mathrm{Zn}, \mathrm{As}, \mathrm{Ag}, \mathrm{Cd}, \mathrm{Pb})$ in the invertebrates $C$. nilotica, P. ovata, and M. bourguignati and the commercial fish species $O$. niloticus and L. niloticus with respect to bioaccumulation, bioindicative aspects, and the potential health risk to consumers.

\section{Materials and Methods}

\section{Study Area Descriptions}

Lake Victoria, shared by Kenya (6\%), Uganda (43\%), and Tanzania (51\%), is the world's largest tropical lake and the second largest freshwater lake in the world, covering a total of $69,000 \mathrm{~km}^{2}$ with a mean depth of $40 \mathrm{~m}$ and maximum depth of $79 \mathrm{~m}$ (Okungu et al. 2005). It is located along the equator between $0.5^{\circ} \mathrm{N}$ and $2.5^{\circ} \mathrm{S}$ and $32^{\circ} \mathrm{E}$ and $34^{\circ} \mathrm{E}$ at an elevation of $1134 \mathrm{~m}$ above sea level, with a large catchment of $195,000 \mathrm{~km}^{2}$. The main river inlet (Kagera) drains through Rwanda, Burundi, Tanzania, and Uganda, while the main river outlet is the Nile (Crul 1995). The Kenyan portion of Lake Victoria lies just south of the equator between $0^{\circ} 6^{\prime} \mathrm{S}$ to $0^{\circ} 32^{\prime} \mathrm{S}$ and $34^{\circ} 13^{\prime} \mathrm{E}$ to $34^{\circ} 52^{\prime} \mathrm{E}$, and it covers an area of approximately $4200 \mathrm{~km}^{2}$ of which $1400 \mathrm{~km}^{2}$ comprises the Winam Gulf, (Lung'ayia et al. 2001). Although Kenya's share of the lake is only $6 \%$, it contributes significantly to internal and external fish markets (FAO 2015). The Winam Gulf (Fig. 1) is a shallow basin with an inshore (mean $4 \mathrm{~m}$, maximum $6 \mathrm{~m}$ depth) and offshore zone (mean $12 \mathrm{~m}$, maximum $43 \mathrm{~m}$ depth) (Crul 1995). The gulf receives high river inflows from western Kenya highlands (Njuru and Hecky 2005). The Lake Victoria basin has an equatorial climate, with temperatures ranging between 20 and $35^{\circ} \mathrm{C}$, and the mean annual rainfall ranges between 1000 and $1500 \mathrm{~mm}$ (Okungu et al. 2005).

The study was performed in five selected sites in the Kenyan part of Lake Victoria both in Winam Gulf and part of the main lake as indicated in Fig. 1. The sampling sites: Asembo Bay (AB), Kisumu City (KM), Kisumu City outskirt (KK), Mainuga (MN), and Rusinga Island (RS) were selected based on the different types and levels of anthropogenic pressures. As noted in Outa et al. (2019), contamination of the water and surface sediment was highest at KM, which is a part of the lake that suffers from the effects of urbanization, with industrial and municipal wastewater discharges from Kisumu City. AB, located on the northern shoreline, and MN to the south, within the mid-region of Winam Gulf, are moderately contaminated by runoff and deposition of sediment from rural farmlands. In contrast, $\mathrm{RS}$ is part of the main lake body with minimal horizontal mixing with the gulf and represents the characteristics of the main lake body in this study. 


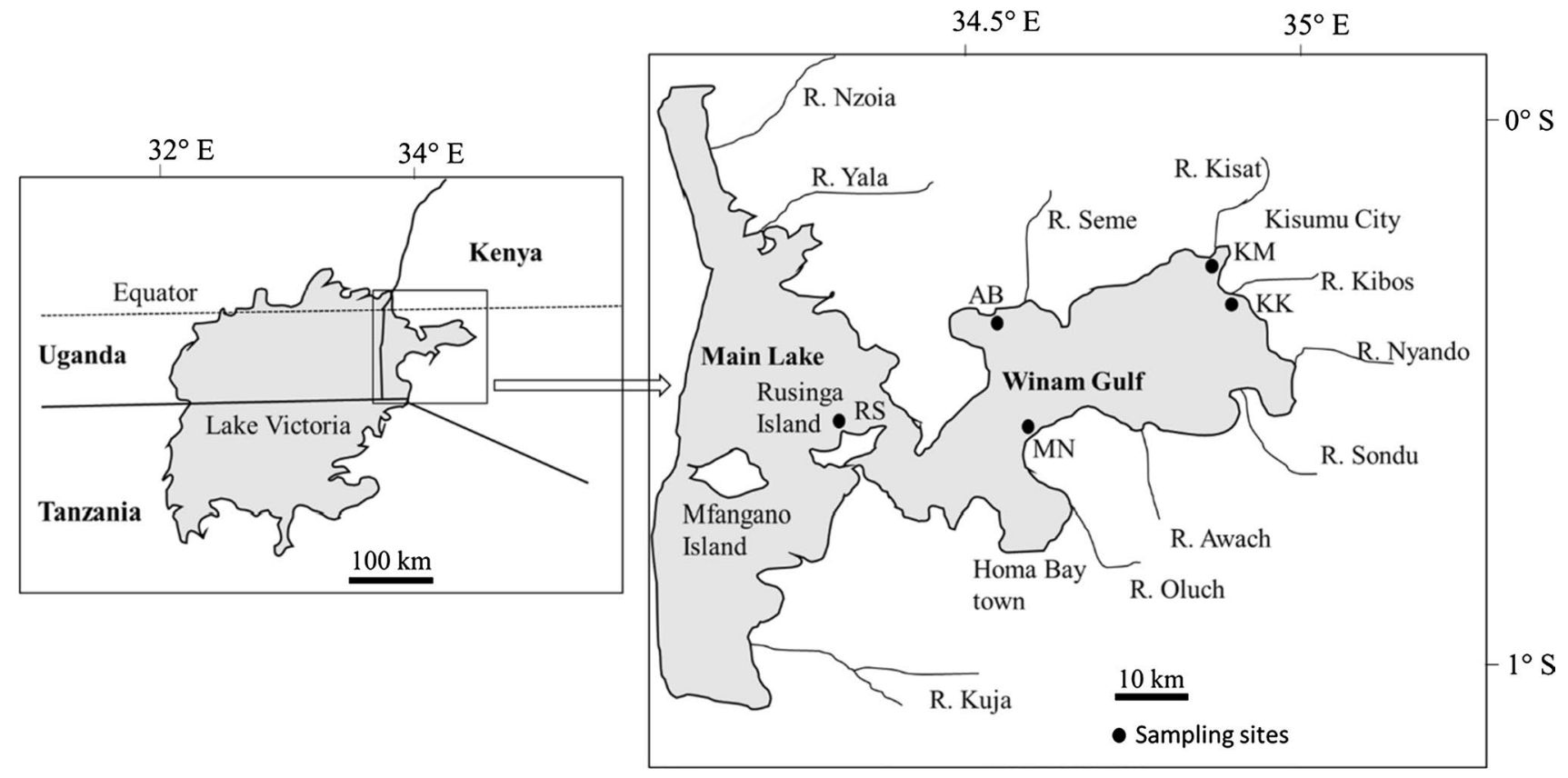

Fig. 1 Map of Lake Victoria indicating the study area and sampling sites. Modified from Okungu et al. (2005). AB: Asembo Bay $\left(0^{\circ} 11^{\prime}\right.$ $\left.10.2^{\prime \prime} \mathrm{S} 34^{\circ} 23^{\prime} 35.8^{\prime \prime} \mathrm{E}\right), \mathrm{KM}$ : Kisumu City $\left(0^{\circ} 05^{\prime} 16.4^{\prime \prime} \mathrm{S} 34^{\circ} 44^{\prime}\right.$

\section{Sampling and Sample Preparation}

Sampling in the lake was conducted between January and July 2017. Caridina nilotica was obtained from AB, KM, and RS using seine nets. The samples were transferred into clean plastic bags, put on ice, and were transported protected from light to Maseno University laboratory in Kisumu City, where they were rinsed with Millipore water. In order to achieve sufficient material for analyses, 15-20 specimens were pooled into $15-\mathrm{ml}$ polypropylene (PP) tubes and ovendried for $48 \mathrm{~h}$ to constant weight at $90^{\circ} \mathrm{C}$. In total, 72 sample were obtained: 26 from $\mathrm{AB}, 24$ from $\mathrm{KM}$, and 22 from RS. Mollusc specimens of $P$. ovata $(\approx 40$-mm shell height $)$ and $M$. bourguignati $(\approx 60-\mathrm{mm}$ shell length) were handpicked (wearing nitrile gloves) from the littoral areas of the study sites. The specimens were transported alive to the laboratory in aerated containers with lake water. For $P$. ovata; 10 specimens from $\mathrm{AB}, 17$ from $\mathrm{KM}, 7$ from $\mathrm{MN}$, and 15 from RS were taken, whereas for M. bourguignati 8 specimens were obtained from MN and RS each. The specimens were kept in aerated lake water for $48 \mathrm{~h}$ for depuration (Gundacker 2000; Chapman 2016): after depuration, the animals were rinsed with Millipore water, individually put into plastic bottles and killed by freezing them at $-20{ }^{\circ} \mathrm{C}$; they were stored in the freezer until further processing. After thawing the mollusks, the soft body was separated from the shells using a ceramic knife and plastic tweezers. For $P$. ovata, the visceral mass and foot were placed into separate PP tubes,
59.0" E), KK: Kisumu City outskirt $\left(0^{\circ} 09^{\prime} 41.4^{\prime \prime} \mathrm{S} 34^{\circ} 44^{\prime} 51.6^{\prime \prime}\right.$ E), MN: Mainuga $\left(0^{\circ} 20^{\prime} 48.7^{\prime \prime} \mathrm{S} 34^{\circ} 29^{\prime} 09.1^{\prime \prime} \mathrm{E}\right)$, and RS: Rusinga Island $\left(0^{\circ} 23^{\prime} 20.5^{\prime \prime} \mathrm{S} 34^{\circ} 11^{\prime} 48.9^{\prime \prime} \mathrm{E}\right)$

whereas in $M$. bourguignati the entire soft body was used. The samples were oven dried for $48 \mathrm{~h}$ to constant weight at $90{ }^{\circ} \mathrm{C}$. Fish were caught using gill nets from $\mathrm{AB}, \mathrm{KM}$, $\mathrm{KK}, \mathrm{MN}$, and RS and transported alive to the laboratory in aerated tanks with lake water. In total, 63 specimens of $O$. niloticus and 46 specimens of $L$. niloticus were obtained. The fish were killed by cervical dislocation and dissected. Tissue samples, approximately $5 \mathrm{~g}$ of dorso-caudal muscle and the same mass of liver, were obtained from each fish using a ceramic knife and plastic tweezers, placed into PP tubes, and dried for $48 \mathrm{~h}$ to constant weight at $90{ }^{\circ} \mathrm{C}$. The samples were shipped to the University of Vienna, Institute of Inorganic Chemistry laboratory for further processing and chemical analysis.

\section{Sample Analyses}

Dried tissue samples were homogenized with a mortar and pestle, and approximately $0.2 \mathrm{~g}$ was digested in $9 \mathrm{ml}$ of $34 \%$ $\mathrm{HNO}_{3}$ (TraceSELECT ${ }^{\circledR}$ Fluka) and $1 \mathrm{ml}$ of $30 \% \mathrm{H}_{2} \mathrm{O}_{2}$ using a microwave MARS XPRESS system (CEM Corporation). The digested samples were transferred into 15 -ml volumetric flasks and brought up to volume using milliQ water. The leachates were filtered through 0.2- $\mu \mathrm{m}$ PTFE pre-syringe filters (VWR). Reference samples comprising $0.2 \mathrm{~g}$ (dry weight) of fish protein (DORM-3 and DOLT-5) obtained from the National Research Council Canada (NRCC) were digested and diluted in the same manner as described above. Trace 
element ( $\mathrm{Cr}, \mathrm{Ni}, \mathrm{Cu}, \mathrm{Zn}, \mathrm{As}, \mathrm{Ag}, \mathrm{Cd}, \mathrm{Pb}$ ) concentrations were determined using total $\mathrm{x}$-ray reflection fluorescence spectrometry (S2 PicoFox TXRF, Bruker) and, when necessary, graphite furnace atomic absorption spectrometry (GFAAS) using a PinAAcle 900Z (Pelkin Elmer).

\section{Statistical Analyses}

Statistical analyses were done using IBM SPSS 21 . The Shapiro-Wilk Test, which is very sensitive to detecting deviations from normality (Mohd and Yap 2011), was used to check for the normality of data distribution. The differences in trace element content of the invertebrates and fish were determined by comparing site-specific means of each species using parametric one-way ANOVA and nonparametric Kruskal-Wallis and Mann-Whitney $U$ tests (for pairwise comparisons) where applicable. For the ANOVA post hoc test, Tukey's HSD was applied for pairwise mean comparisons where homogeneity of variance was established, whereas the Games Howell test was applied for unequal sample sizes and variances (Games and Howell 1976; Kim 2015). In each of the sampling sites, intraspecific differences in trace element accumulation and partitioning in the foot and viscera of mollusks and in muscle and liver tissue of fish were compared using the parametric Student's $t$ test and nonparametric Mann-Whitney $U$ test where appropriate. All differences were tested for significance at $p<0.05$. The correlations between trace elements concentrations in the invertebrates and fish were tested for significance using the parametric Pearson's correlation test and nonparametric Spearman's rank correlation test where applicable. Similarly, we tested the correlations between element concentrations in muscle and liver tissue in relation with total length (TL) of fish.

The bioaccumulation factors (BAFs) were determined according to the formula:

$\operatorname{BAF}_{\left(\frac{x}{y}\right)}=\frac{\text { Concentration of element in } x}{\text { Concentration of element in } y}$.

In which the variables $\mathrm{x}$ and $\mathrm{y}$ stand for matrices that are compared to each other, such as sediment, invertebrate, and fish tissue. Element concentrations in the sediment were based on data from Outa et al. (2019).

\section{Risk Assessment}

The body trace element burden $(\mathrm{mg} / \mathrm{kg} \mathrm{dw})$ of mollusks and fish muscle obtained in our study were converted to fresh weight by applying a conversion factor of 0.2 based on an estimated water content of $80 \%$ (Ongeri et al. 2012; Heuzé and Tran 2017). The trace element content of mollusks was compared with existing maximum limits for food safety (EU 2008; CFDA 2014; FAO/WHO 2017). The target hazard quotients (THQ) were determined for trace elements to assess the risk to people who consume $O$. niloticus and $L$. niloticus in the region. THQ is the ratio between the potential exposure to a substance and the reference dose (level at which no adverse effects are expected) (USEPA 2018a). THQ values $>1$ were regarded to pose a risk to human fish consumers in relation to a specific element, and THQ $\leq 1$ meant no health risk. A THQ of 0.1 was later suggested for noncarcinogenic pollutants to consider additive effects (USEPA 2018a). For calculation, the standard equation inputs for fish consumption given by USEPA were used, with the exception of body weight, to reflect the local realities. USEPA uses a body weight (Bwa) of $70 \mathrm{~kg}$, whereas the average body weight in Africa is $60.7 \mathrm{~kg}$ (Walpole et al. 2012), which we used. The equation used to determine THQ (USEPA 2018b) is as follows:

$\mathrm{THQ}=\frac{\mathrm{EF} \times \mathrm{ED} \times \mathrm{IRF} \times \mathrm{C}}{\mathrm{RfDo} \times \mathrm{BWa} \times \mathrm{AT}}$

The variables in the equation are defined as follows: EF is the exposure frequency (350 days/year); ED is the exposure duration (26 years); IRF is the average fish consumption per day. The per capita fish consumption in Kenya is $4.5 \mathrm{~kg}$ per year (FAO 2015), which translates to $0.0123 \mathrm{~kg} /$ day. C is the trace element concentration in the edible portion of fish (element muscle content, $\mathrm{mg} / \mathrm{kg} \mathrm{ww}$ ); RfDo is the oral reference dose $(\mathrm{mg} / \mathrm{kg} /$ day) according to regional screening levels (USEPA 2018c); Bwa is the average body weight $(60.7 \mathrm{~kg})$; and AT is the average time for noncarcinogens $(\mathrm{AT}=365$ days $\times \mathrm{ED}=9490$ days $)$.

\section{Results and Discussion}

Recovery rates for elemental analyses in reference samples are shown in Table 1. The total lengths and weights of the fish specimens are given in SM Table 1. Due to the high mobility of L. niloticus, we treated all fish for this study as one sample, whereas values for $O$. niloticus were calculated per site. With the exception of $\mathrm{Cu}$ and $\mathrm{Ag}$, which were highest in $O$. niloticus liver, the invertebrates had the highest concentrations of the trace elements measured in this study. The levels of most trace elements were higher in the liver than in the muscle of fish (Tables 2, 3, 4). In freshwater fish, the liver stores and detoxifies various trace elements, hence accumulating them to higher levels compared with muscle tissue (Coetzee et al. 2002; Luczynska et al. 2018; Plessl et al. 2019). Similarly, the levels of most trace elements in invertebrates were higher in the viscera than the foot. These results agree with various studies on mollusks (Gundacker 2000; Deng et al. 2008; Bao et al. 2018). Relatively low concentrations of trace elements in 
Table 1 Recovery rates for the analyses of certified reference material (NRCC) for the respective methods

\begin{tabular}{lllccr}
\hline Element & Method & Reference material & $\begin{array}{l}\text { Reference value } \\
(\mathrm{mg} / \mathrm{kg})\end{array}$ & $\begin{array}{l}\text { Measured value } \\
(\mathrm{mg} / \mathrm{kg})\end{array}$ & $\begin{array}{l}\text { Recovery } \\
\text { rate }(\%)\end{array}$ \\
\hline $\mathrm{Cr}$ & GF-AAS & DORM-3 & $1.89 \pm 0.17$ & $1.89 \pm 0.11$ & 99.3 \\
$\mathrm{Ni}$ & GF-AAS & DOLT-3 & $2.72 \pm 0.35$ & $3.05 \pm 0.18$ & 108.7 \\
$\mathrm{Cu}$ & TXRF & DOLT-5 & $35 \pm 2.4$ & $34.1 \pm 0.8$ & 97.3 \\
$\mathrm{Zn}$ & TXRF & DOLT-5 & $105.3 \pm 5.4$ & $107.2 \pm 5.5$ & 101.8 \\
$\mathrm{As}$ & GF-AAS & DOLT-5 & $34.6 \pm 2.4$ & $30.3 \pm 3.7$ & 87.6 \\
$\mathrm{Ag}$ & GF-AAS & DOLT-3 & $1.2 \pm 0.07$ & $1.19 \pm 0.28$ & 99.5 \\
$\mathrm{Cd}$ & GF-AAS & DOLT-3 & $19.4 \pm 0.6$ & $19.7 \pm 0.5$ & 101.5 \\
$\mathrm{~Pb}$ & GF-AAS & DOLT-3 & $0.32 \pm 0.05$ & $0.33 \pm 0.01$ & 104.2 \\
\hline
\end{tabular}

\begin{tabular}{llrcccc}
\hline Species & Site & \multicolumn{1}{c}{$n$} & \multicolumn{1}{l}{$\mathrm{Cr}$} & $\mathrm{Ni}$ & $\mathrm{Cu}$ \\
\hline C. niloticus & $\mathrm{AB}$ & 26 & $3.27^{\mathrm{a}} \pm 3.0$ & $2.57^{\mathrm{a}} \pm 2.0$ & $148^{\mathrm{a}} \pm 12$ & $69.8^{\mathrm{a}} \pm 7.6$ \\
& $\mathrm{KM}$ & 24 & $3.58^{\mathrm{a}} \pm 3.2$ & $1.26^{\mathrm{b}} \pm 1.5$ & $115^{\mathrm{be}} \pm 11$ & $72.8^{\mathrm{a}} \pm 23$ \\
& $\mathrm{RS}$ & 22 & $1.19^{\mathrm{be}} \pm 1.0$ & $0.791^{\mathrm{c}} \pm 0.69$ & $77.4^{\mathrm{c}} \pm 7.1$ & $72.6^{\mathrm{a}} \pm 7.0$ \\
P. ovata foot & $\mathrm{AB}$ & 10 & $0.501^{\mathrm{c}} \pm 1.1$ & $1.45^{\mathrm{ab}} \pm 1.9$ & $73.1^{\mathrm{b}} \pm 26$ & $65.7^{\mathrm{ac}} \pm 8.6$ \\
& $\mathrm{KM}$ & 17 & $0.607^{\mathrm{c}} \pm 1.0$ & $1.72^{\mathrm{b}} \pm 3.2$ & $108^{\mathrm{be}} \pm 71$ & $54.3^{\mathrm{b}} \pm 8.8$ \\
& $\mathrm{MN}$ & 7 & $0.271^{\mathrm{d}} \pm 0.19$ & $0.325^{\mathrm{c}} \pm 0.2$ & $94.2^{\mathrm{be}} \pm 80$ & $49.7^{\mathrm{b}} \pm 5.1$ \\
& $\mathrm{RS}$ & 15 & $0.570^{\mathrm{c}} \pm 0.92$ & $0.879^{\mathrm{c}} \pm 2.1$ & $112^{\mathrm{bc}} \pm 79$ & $61.4^{\mathrm{c}} \pm 19$ \\
P. ovata viscera & AB & 10 & $5.05^{\mathrm{a}} \pm 2.0$ & $36.1^{\mathrm{d}} \pm 13$ & $57.8^{\mathrm{d}} \pm 13$ & $1350^{\mathrm{d}} \pm 433$ \\
& $\mathrm{KM}$ & 17 & $3.75^{\mathrm{a}} \pm 2.7$ & $12.3^{\mathrm{e}} \pm 9.9$ & $135^{\mathrm{e}} \pm 66$ & $893^{\mathrm{de}} \pm 769$ \\
& $\mathrm{MN}$ & 7 & $2.13^{\mathrm{e}} \pm 1.4$ & $20.1^{\mathrm{f}} \pm 7.8$ & $105^{\mathrm{be}} \pm 71$ & $638^{\mathrm{e}} \pm 336$ \\
& $\mathrm{RS}$ & 15 & $2.41^{\mathrm{e}} \pm 1.9$ & $9.63^{\mathrm{e}} \pm 3.4$ & $90.3^{\mathrm{bc}} \pm 83$ & $1361^{\mathrm{d}} \pm 1132$ \\
M. bourguignati & MN & 8 & $3.72^{\mathrm{a}} \pm 1.4$ & $4.85^{\mathrm{a}} \pm 2.4$ & $9.15^{\mathrm{f}} \pm 1.6$ & $829^{\mathrm{e}} \pm 460$ \\
& $\mathrm{RS}$ & 8 & $3.71^{\mathrm{a}} \pm 3.5$ & $1.32^{\mathrm{b}} \pm 1.0$ & $6.45^{\mathrm{g}} \pm 1.9$ & $383^{\mathrm{f}} \pm 176$ \\
\hline
\end{tabular}

Mean values followed by same letters for each element do not differ significantly $(p>0.05)$

\begin{tabular}{|c|c|c|c|c|c|c|}
\hline Species & Site & $n$ & As & $\mathrm{Ag}$ & $\mathrm{Cd}$ & $\mathrm{Pb}$ \\
\hline \multirow[t]{3}{*}{ C. niloticus } & $\mathrm{AB}$ & 26 & $0.828^{\mathrm{a}} \pm 0.13$ & $0.212^{\mathrm{a}} \pm 0.03$ & $0.069^{\mathrm{a}} \pm 0.01$ & $4.57^{\mathrm{a}} \pm 3.6$ \\
\hline & KM & 24 & $0.858^{\mathrm{a}} \pm 0.15$ & $0.422^{c} \pm 0.04$ & $0.067^{\mathrm{a}} \pm 0.01$ & $4.71^{\mathrm{a}} \pm 2.7$ \\
\hline & $\mathrm{RS}$ & 22 & $0.957^{b} \pm 0.06$ & $0.096^{\mathrm{b}} \pm 0.01$ & $0.046^{\mathrm{b}} \pm 0.005$ & $4.38^{\mathrm{a}} \pm 2.3$ \\
\hline \multirow[t]{4}{*}{ P. ovata foot } & $\mathrm{AB}$ & 10 & $0.277^{c} \pm 0.09$ & $0.255^{\mathrm{a}} \pm 0.09$ & $0.178^{\mathrm{ah}} \pm 0.09$ & $0.282^{\mathrm{b}} \pm 0.34$ \\
\hline & KM & 17 & $0.717^{\mathrm{a}} \pm 0.43$ & $0.660^{\mathrm{d}} \pm 0.25$ & $0.060^{\mathrm{ab}} \pm 0.03$ & $0.735^{\mathrm{d}} \pm 0.76$ \\
\hline & $\mathrm{MN}$ & 7 & $0.401^{c} \pm 0.10$ & $0.300^{\mathrm{a}} \pm 0.27$ & $0.035^{\mathrm{bc}} \pm 0.03$ & $0.159^{\mathrm{b}} \pm 0.06$ \\
\hline & $\mathrm{RS}$ & 15 & $0.371^{c} \pm 0.20$ & $0.354^{\mathrm{a}} \pm 0.23$ & $0.026^{c} \pm 0.02$ & $0.201^{\mathrm{b}} \pm 0.33$ \\
\hline \multirow[t]{4}{*}{ P. ovata viscera } & $\mathrm{AB}$ & 10 & $0.497^{\mathrm{d}} \pm 0.13$ & $0.148^{\mathrm{b}} \pm 0.05$ & $5.57^{\mathrm{d}} \pm 3.03$ & $1.86^{\mathrm{c}} \pm 1.4$ \\
\hline & $\mathrm{KM}$ & 17 & $0.623^{\mathrm{ad}} \pm 0.27$ & $0.711^{\mathrm{d}} \pm 0.29$ & $2.51^{\mathrm{e}} \pm 2.87$ & $15.5^{\mathrm{e}} \pm 30$ \\
\hline & MN & 7 & $0.366^{c} \pm 0.11$ & $0.356^{\mathrm{a}} \pm 0.43$ & $1.32^{\mathrm{e}} \pm 0.52$ & $1.56^{\mathrm{c}} \pm 0.48$ \\
\hline & RS & 15 & $0.195^{\mathrm{e}} \pm 0.06$ & $0.272^{\mathrm{e}} \pm 0.17$ & $0.599^{f} \pm 0.42$ & $0.479^{\mathrm{d}} \pm 0.40$ \\
\hline \multirow[t]{2}{*}{ M. bourguignati } & $\mathrm{MN}$ & 8 & $0.123^{\mathrm{e}} \pm 0.05$ & $0.035^{\mathrm{f}} \pm 0.02$ & $0.463^{\mathrm{g}} \pm 0.21$ & $1.42^{\mathrm{c}} \pm 0.68$ \\
\hline & RS & 8 & $0.091^{\mathrm{e}} \pm 0.04$ & $0.021^{\mathrm{f}} \pm 0.01$ & $0.274^{\mathrm{h}} \pm 0.20$ & $0.736^{\mathrm{b}} \pm 0.97$ \\
\hline
\end{tabular}

Mean values followed by same letters for each element do not differ significantly $(p>0.05)$
Table 3 Mean concentration $( \pm \mathrm{SD})$ of nonessential trace elements $(\mathrm{mg} / \mathrm{kg} \mathrm{dw})$ in invertebrates from the study sites
Table 2 Mean concentrations $( \pm \mathrm{SD})$ of essential trace elements $(\mathrm{mg} / \mathrm{kg} \mathrm{dw})$ in invertebrates from the study sites other mollusk soft body parts, such as the foot and head, indicate that the snails have developed mechanisms to regulate the translocation of trace elements from the viscera (Deng et al. 2008). Regarding human consumption, calculated THQs for $\mathrm{Cr}, \mathrm{Ni}, \mathrm{Cu}$, and $\mathrm{Zn}$ in fish muscle were below 0.1 ; the consumption of these fish therefore poses no health risk to humans. In the following, each of the elements are briefly discussed separately: 
Table 4 Mean concentration $( \pm \mathrm{SD})$ of trace elements in muscle and liver $(\mathrm{mg} / \mathrm{kg} \mathrm{dw})$ of fish in the study area: site specific for $O$. niloticus and pooled samples for L. niloticus

\begin{tabular}{|c|c|c|c|c|c|c|c|c|c|c|}
\hline Species & Site & Tissue & $n$ & $\mathrm{Cr}$ & $\mathrm{Ni}$ & $\mathrm{Cu}$ & $\mathrm{Zn}$ & $\mathrm{Ag}$ & $\mathrm{Cd}$ & $\mathrm{Pb}$ \\
\hline \multirow[t]{10}{*}{ O. niloticus } & \multirow[t]{2}{*}{$\mathrm{AB}$} & Muscle & 9 & $0.131^{\mathrm{a}} \pm 0.08$ & $0.047^{\mathrm{a}} \pm 0.03$ & $0.652^{\mathrm{a}} \pm 0.21$ & $23.3^{\mathrm{a}} \pm 6.3$ & $<0.015$ & $<0.005$ & $0.158^{\mathrm{a}} \pm 0.12$ \\
\hline & & Liver & 9 & $0.304^{b} \pm 0.39$ & $0.187^{\mathrm{b}} \pm 0.02$ & $240^{\mathrm{cd}} \pm 66$ & $130^{\mathrm{cd}} \pm 12$ & $0.584^{\mathrm{a}} \pm 0.11$ & $0.062^{\mathrm{a}} \pm 0.01$ & $0.494^{\mathrm{b}} \pm 0.15$ \\
\hline & \multirow[t]{2}{*}{$\mathrm{KM}$} & Muscle & 20 & $0.119^{\mathrm{a}} \pm 0.08$ & $<0.040$ & $2.12^{\mathrm{b}} \pm 1.7$ & $23.0^{\mathrm{a}} \pm 4.2$ & $<0.015$ & $<0.005$ & $0.129^{\mathrm{a}} \pm 0.11$ \\
\hline & & Liver & 20 & $0.371^{\mathrm{b}} \pm 0.50$ & $0.190^{\mathrm{b}} \pm 0.08$ & $320^{\mathrm{cd}} \pm 231$ & $98.4^{\mathrm{c}} \pm 18$ & $3.45^{\mathrm{b}} \pm 1.49$ & $0.197^{\mathrm{b}} \pm 0.21$ & $0.552^{\mathrm{b}} \pm 0.32$ \\
\hline & \multirow[t]{2}{*}{ KK } & Muscle & 9 & $0.127^{\mathrm{a}} \pm 0.09$ & $<0.040$ & $0.766^{\mathrm{a}} \pm 0.16$ & $17.2^{\mathrm{b}} \pm 2.7$ & $<0.015 \pm$ & $<0.005$ & $0.123^{\mathrm{a}} \pm 0.11$ \\
\hline & & Liver & 9 & $0.379^{\mathrm{b}} \pm 0.30$ & $0.188^{\mathrm{b}} \pm 0.05$ & $465^{c} \pm 689$ & $127^{\mathrm{cd}} \pm 15$ & $0.640^{\mathrm{a}} \pm 0.55$ & $0.067^{\mathrm{a}} \pm 0.08$ & $0.486^{\mathrm{b}} \pm 0.14$ \\
\hline & \multirow[t]{2}{*}{$\mathrm{MN}$} & Muscle & 6 & $0.360^{\mathrm{ab}} \pm 0.63$ & $<0.040$ & $0.826^{\mathrm{a}} \pm 0.37$ & $23.2^{\mathrm{a}} \pm 6.3$ & $<0.015$ & $<0.005$ & $0.085^{\mathrm{a}} \pm 0.03$ \\
\hline & & Liver & 6 & $0.252^{\mathrm{ab}} \pm 0.19$ & $0.180^{\mathrm{b}} \pm 0.03$ & $178^{\mathrm{d}} \pm 74$ & $89.6^{\mathrm{c}} \pm 7.7$ & $0.584^{\mathrm{a}} \pm 0.31$ & $0.058^{\mathrm{a}} \pm 0.03$ & $0.083^{\mathrm{a}} \pm 0.02$ \\
\hline & \multirow[t]{2}{*}{$\mathrm{RS}$} & Muscle & 20 & $0.102^{\mathrm{a}} \pm 0.06$ & $0.072^{\mathrm{a}} \pm 0.03$ & $0.720^{\mathrm{a}} \pm 0.35$ & $19.4^{\mathrm{ab}} \pm 4.5$ & $<0.015$ & $<0.005$ & $0.108^{\mathrm{a}} \pm 0.08$ \\
\hline & & Liver & 20 & $0.367^{b} \pm 0.35$ & $0.166^{\mathrm{b}} \pm 0.07$ & $170^{\mathrm{d}} \pm 123$ & $87.5^{\mathrm{c}} \pm 10$ & $0.657^{\mathrm{a}} \pm 0.50$ & $0.333^{c} \pm 0.27$ & $0.125^{\mathrm{a}} \pm 0.06$ \\
\hline \multirow[t]{2}{*}{ L. niloticus } & & Muscle & 46 & $0.150^{\mathrm{a}} \pm 0.17$ & $0.095^{\mathrm{c}} \pm 0.03$ & $1.08^{\mathrm{a}} \pm 0.22$ & $18.3^{\mathrm{ab}} \pm 3.2$ & $<0.015$ & $<0.005$ & $0.088^{\mathrm{a}} \pm 0.09$ \\
\hline & & Liver & 46 & $0.303^{\mathrm{b}} \pm 0.28$ & $0.149^{\mathrm{b}} \pm 0.09$ & $46.8^{\mathrm{e}} \pm 15.8$ & $157^{\mathrm{d}} \pm 30$ & $0.032^{c} \pm 0.02$ & $0.067^{\mathrm{a}} \pm 0.05$ & $0.413^{\mathrm{b}} \pm 0.16$ \\
\hline
\end{tabular}

Values followed by same letters for each element do not differ significantly $(p>0.05)$

\section{$\mathrm{Cr}$}

The essentiality of chromium for plants and animals is still under discussion (Markert et al. 2015), but it is a well-known pollutant of aquatic environments worldwide (Pure Earth and Green Cross 2016). As indicated in Table 2, Cr concentrations in the $C$. nilotica and $P$. ovata viscera showed distinct spatial variation (one-way ANOVA, $F=5.476, p=0.006$ and $F=3.827, p=0.016$ respectively), which we did not observe in $P$. ovata foot or in M. bourguignati. Caridina nilotica from the less disturbed RS site had lower concentrations than samples from the $\mathrm{AB}$ and $\mathrm{KM}$ sites (Games Howell test, $p=0.006$ and 0.005 , respectively). Similarly, $P$. ovata viscera from RS had lower concentrations compared with $\mathrm{AB}$ and KM (Tukey HSD test, $p=0.020$ and 0.046 , respectively). This agrees with the results for $\mathrm{Cr}$ in sediments from these sampling sites (Outa et al. 2019), where concentrations were significantly lower at RS. These findings indicate that $C$. nilotica and $P$. ovata viscera are potentially good indicators for $\mathrm{Cr}$ contamination, because their metal content corresponds with environmental concentrations. There are very few studies on $\mathrm{Cr}$ accumulation for invertebrates and virtually no records of $\mathrm{Cr}$ levels in $C$. nilotica, $P$. ovata, and M. bourguignati. Tu et al. (2008) reported $\mathrm{Cr}$ mean body concentrations ranging from 0.167 to $0.633 \mathrm{mg} / \mathrm{kg} \mathrm{dw}$ in the caridean river prawn Macrobrachium rosenbergii (Palaemonidae) from the Mekong River Delta, Vietnam. This is even lower than the mean $\mathrm{Cr}$ concentration recorded in $C$. nilotica from the RS site $(1.19 \pm 1.0 \mathrm{mg} / \mathrm{kg} \mathrm{dw})$. Regarding human consumption, most international regulations do not provide maximum values for $\mathrm{Cr}$. One exception is China, where a maximum level of $2 \mathrm{mg} / \mathrm{kg}$ ww is allowed in mollusks (CFDA 2014). All levels from our study were below this, and therefore no risks for consumers are expected.
Chromium concentrations in fish liver were significantly higher than in muscle in all samples, and there was no significant difference between the two fish species (Table 4). Comparing the sample sites, no significant differences were recorded either in muscle or liver (Kruskal-Wallis test, $X^{2}(4)=2.263, p=0.688$ and $X^{2}(4)=2.073, p=0.722$, respectively). In fish, $\mathrm{Cr}$ is predominantly taken up through the gills and distributed via the blood to the tissues, with little or no bioconcentration at environmentally relevant concentrations (Reid 2012). As noted by Outa et al. (2019), the levels of dissolved $\mathrm{Cr}$ in Lake Victoria water were generally low (mean: $0.14-0.39 \mu \mathrm{g} / \mathrm{l}$ ), and this may be the main reason for the low values recorded in fish tissue. Contrary to the findings of Coetzee et al. (2002), who recorded positive correlations between $\mathrm{Cr}$ tissue content and size of omnivorous Clarias gariepinus and the benthic feeder Labeo umbratus, fish size did not correlate to tissue $\mathrm{Cr}$ concentrations. Because no data have been published on the accumulation of $\mathrm{Cr}$ in fish from Lake Victoria, we compared our findings to those from other freshwater bodies in the region. Plessl et al. (2017) reported mean $\mathrm{Cr}$ concentrations of $0.42 \pm 0.33$ and $1.65 \pm 1.24 \mathrm{mg} / \mathrm{kg} \mathrm{dw}$ in muscle and liver, respectively, in Tilapia zillii from Lake Naivasha (Kenya), which are higher than in the fish species from our study.

\section{$\mathbf{N i}$}

Very few studies on $\mathrm{Ni}$ accumulation in invertebrates are available, and no records on $\mathrm{Ni}$ concentrations in $C$. nilotica, $P$. ovata, or $M$. bourguignati. In the current study, the variations in concentrations in crustacean and mollusc samples from the study sites (Table 2) did not correspond with data on the sediments at those sites as reported in Outa et al. (2019). Pila ovata viscera had the highest concentrations 
$(9.63-36.1 \mathrm{mg} / \mathrm{kg} \mathrm{dw})$, which were at least four times higher than in the other invertebrate tissues. Compared with other studies, lower Ni levels have been reported in mollusks: $0.02-1.54 \mathrm{mg} / \mathrm{kg} \mathrm{dw}$ in Pomacea caniliculata from the Mae Klong River, Thailand (Peña, 2017) and a mean concentration of $5 \mathrm{mg} / \mathrm{kg} \mathrm{dw}$ in the viscera of the bivalve Unio pictorum from Lake Maggiore, Italy (Ravera et al. 2003). Because the levels in Lake Victoria water and sediment were generally low, except for the MN site (Outa et al. 2019), the high levels of $\mathrm{Ni}$ in P. ovata viscera from our study warrant further investigation.

In fish, Ni can be taken up through the gills or olfactory epithelium during waterborne exposures or through the gut during dietary exposures. It preferentially accumulates in the kidneys (Pyle and Couture 2012). Higher concentrations were recorded in the muscle of L. niloticus than in O. niloticus (Table 4), which might be due to differences in physiological regulation in the two fish species. Moderate negative correlations occurred between TL and Ni concentration in $L$. niloticus liver (Spearman's rank test, $r_{\mathrm{s}}=-0.432, p<0.01$ ). This agrees with Coetzee et al. (2002), who noted that the Ni content of fish was predominantly negatively correlated with fish length. The Ni content of $O$. niloticus in our study did not correspond to its concentration in the environment, possibly due to effective physiological regulation. Other studies report different results; Mwamburi (2013) did not detect Ni in the muscle tissue of three fish species (O. leucostictus, $T$. zillii, Micropterus salmoides) from Lake Naivasha, Kenya. In our study, the value was below the LOD $(0.040 \mathrm{mg} / \mathrm{kg}$ $\mathrm{dw}$ ) in muscle tissue of $O$. niloticus in three of the sampling sites (KM, KK, MN) but was detected in the rest of the samples, albeit at low levels. In the rather unpolluted Vaal Dam in South Africa, similar levels were reported from cyprinid fish (Gilbert et al. 2017). Much higher Ni concentrations were reported from the polluted Olifants Rivers System (South Africa): 14.2 and $19.4 \mathrm{mg} / \mathrm{kg} \mathrm{dw}$ in muscle tissue, and 16.6 and $26.1 \mathrm{mg} / \mathrm{kg} \mathrm{dw}$ in liver tissue of $C$. gariepinus and L. umbratus, respectively (Coetzee et al. 2002).

\section{$\mathrm{Cu}$}

$\mathrm{Cu}$ is an essential element whose levels in tissues are well regulated in invertebrates (Depledge et al. 1998; Rainbow 2007) and fish (Grossel 2012). Data from mollusks and crustaceans did not reflect the sediment pollution levels reported at KM (Outa et al. (2019)). The $\mathrm{Cu}$ concentrations in the foot and viscera of $P$. ovata did not differ significantly (Mann-Whitney test, $U=1141, p=0.672$ ), indicating that translocation to various organs, including the foot is not restricted. Pila ovata accumulated 10-18 times more $\mathrm{Cu}$ than $M$. bourguignati. This finding concurs with Gundacker (2000), who reported that freshwater unionid bivalves had extremely low $\mathrm{Cu}$ contents compared with their gastropod counterparts in urban river habitats in Austria. This variation was attributed to different regulation capacities for $\mathrm{Cu}$ by the mollusc taxa. As indicated in SM Table 2, the BAF values for $\mathrm{Cu}$ in the invertebrates in relation to sediment were $>1$ : the highest BAFs were 5.26 ( $C$. nilotica), 4.40 ( $P$. ovata viscera), and 3.96 ( $P$. ovata foot). Comparing $\mathrm{Cu}$ levels with other studies, Abdennour et al. (2000) reported mean range values of $44.5-123 \mathrm{mg} / \mathrm{kg}$ dw in the shrimp Atyaephyra desmarestii at four sites in Algeria, which is comparable with values for $C$. nilotica $(77.4-148 \mathrm{mg} / \mathrm{kg} \mathrm{dw})$. In mollusks, lower levels were recorded in snails and bivalves from less contaminated freshwater bodies. For instance, in the Ipoba Stream, Nigeria, Ezemonye et al. (2006) recorded Cu concentrations ranging from 2.0 to $5.8 \mathrm{mg} / \mathrm{kg} \mathrm{dw}$ in the viscera of $P$. ovata, whereas mean values of 2.1 and $4.5 \mathrm{mg} / \mathrm{kg} \mathrm{dw}$ were recorded in the bivalve $M$. spekei from two sites in Lake Tanganyika, Tanzania (Foxall et al. 2000). The bivalve $M$. bourguignati samples from the two sites in our study had higher levels: $6.45 \pm 1.6$ and $9.15 \pm 1.9 \mathrm{mg} / \mathrm{kg} \mathrm{dw}$ from $\mathrm{MN}$ and RS, respectively. At the same time, the $P$. ovata viscera values from our sites are in the same magnitude as data on Pomacea canaliculata viscera $(60-170 \mathrm{mg} / \mathrm{kg} \mathrm{dw})$ from the polluted Fankou stream in southern China. In fish, $\mathrm{Cu}$ is predominantly taken up from the diet through the intestines and directly from the water across the gill epithelia (Grossel 2012). The levels in the muscle of $O$. niloticus at the KM site were higher than at all other sites (Table 4), corresponding with the $\mathrm{Cu}$ pollution in the sediment at KM. Accordingly, O. niloticus muscle tissue is a potential indicator for $\mathrm{Cu}$ contamination. This also indicates that physiological $\mathrm{Cu}$ regulation in fish may break down in individuals living in habitats polluted with $\mathrm{Cu}$. At all sampling sites, the liver values of O. niloticus were higher than the corresponding levels in the surface sediment (SM; Table 2). The levels in O. niloticus liver were 4-10 times higher than in the liver of $L$. niloticus. The omnivorous inshore-dwelling $O$. niloticus is probably exposed to more $\mathrm{Cu}$ uptake through the diet and from contact with the contaminated water and surface sediment. $\mathrm{Cu}$ in fish tissue generally shows weak or negative correlations with fish size (Szarek-Gwiazda and Amirowicz 2006; Luczynska et al. 2018). That also was the case for the $\mathrm{Cu}$ concentration in the muscle tissue of L. niloticus: values showed a moderate negative correlation with TL (Spearman's rank test, $\left.r_{\mathrm{s}}=-0.456, p<0.0001\right)$. Nonetheless, the $\mathrm{Cu}$ content in $O$. niloticus liver had high positive correlations with TL (Spearman's rank test, $\left.r_{\mathrm{s}}=0.785, p<0.0001\right)$ at $\mathrm{KM}$, where the $\mathrm{Cu}$ levels were highest in surface sediment. This agrees with the findings of Çoğun et al. (2003), who recorded high positive correlations between $O$. niloticus size and liver content in $\mathrm{Cu}$ exposure experiments. Compared with other studies, the $\mathrm{Cu}$ levels in the muscle tissue of both fish species and in the liver of L. niloticus are of the same magnitude as in the same fish species from Winam Gulf (Ongeri et al. 2012) and 
from Lake Nasser, Egypt (Mohamed 2008). The mean concentrations of $\mathrm{Cu}$ in O. niloticus liver (170-465 mg/kg dw) from our study sites, however, were higher than in the same species from Lake Nasser (67.1-102 mg/kg dw) (Mohamed 2008) and also higher than in T. zillii $(123 \pm 148 \mathrm{mg} / \mathrm{kg} \mathrm{dw})$ from Lake Naivasha (Plessl et al. 2017). The higher Cu values in $O$. niloticus liver from our study reflect the higher levels in the study area.

\section{Zn}

The body concentration of $\mathrm{Zn}$, an essential element, is regulated to relatively constant levels in invertebrates (Depledge et al. 1998; Rainbow 2007) and freshwater fish (Hogstrand 2012). In our study, elevated levels of $\mathrm{Zn}$ at KM (Outa et al. 2019) were not reflected in the fauna. This might indicate that the $\mathrm{Zn}$ in the invertebrates and fish were within their internal regulation capacities. As indicated for SM in Table 2, BAF values for $\mathrm{Zn}$ in the $P$. ovata viscera and $M$. bourguignati in relation to sediment levels were $>1$; the highest BAFs were 16.5 (P. ovata viscera) and 7.89 ( $M$. bourguignati).

Compared with other studies, Abdennour et al. (2000) reported $\mathrm{Zn}$ mean range values of $37-73 \mathrm{mg} / \mathrm{kg} \mathrm{dw}$ in the atyid shrimp A. desmarestii in Algeria (comparable to the $69.8-72.9 \mathrm{mg} / \mathrm{kg} \mathrm{dw}$ in C. nilotica from our study stites). The mean concentrations in $M$. bourguignati and $P$. ovata viscera from our study sites (383-1361 $\mathrm{mg} / \mathrm{kg} \mathrm{dw}$ ) are higher than in molluscs from other areas in Africa. For instance, mean $\mathrm{Zn}$ concentrations in the viscera of $P$. ovata from various sites in the Ikpoba River in Nigeria ranged from 23.6 to $45.2 \mathrm{mg} / \mathrm{kg}$ dw (Ezemonye et al. 2006). Mwamburi (2013) recorded a mean concentration of $207 \mathrm{mg} / \mathrm{kg}$ in Sphaerium sp. from Lake Victoria, whereas Foxall et al. (2000) reported means of 72 and $76 \mathrm{mg} / \mathrm{kg} \mathrm{dw}$ in M. spekei from Lake Tanganyika, Tanzania. Importantly, Deng et al. (2008) reported much higher levels in the viscera of Pomacea canaliculata in Fankou stream (southern China), which received effluent from a $\mathrm{Zn} / \mathrm{Pb}$ mine. There, mean $\mathrm{Zn}$ concentrations in P. canaliculata ranged from 3000 to $6400 \mathrm{mg} /$ $\mathrm{kg}$. Regarding the risk for consumption by humans, the mean levels of $\mathrm{Zn}$ in $P$. ovata viscera at AB $(1350 \pm 433 \mathrm{mg} / \mathrm{kg}$ $\mathrm{dw}), \mathrm{KM}(893 \pm 769 \mathrm{mg} / \mathrm{kg} \mathrm{dw})$, and RS $(1361 \pm 1132 \mathrm{mg} /$ $\mathrm{kg} \mathrm{dw})$ and M. bourguignati at MN $(829 \pm 460 \mathrm{mg} / \mathrm{kg} \mathrm{dw})$ surpassed various national food safety limits: Australian Legal Requirements for Food Safety $(750 \mathrm{mg} / \mathrm{kg} \mathrm{dw})$, Ministry of Public Health, Thailand $(667 \mathrm{mg} / \mathrm{kg} \mathrm{dw})$, and Brazilian Ministry of Health $(250 \mathrm{mg} / \mathrm{kg} \mathrm{dw}$ ) (Yap et al. 2004). According to Hogstrand (2012), due to slower metabolism in older fish, $\mathrm{Zn}$ accumulation and fish size are either negatively correlated or lack any significant relationship. Our study also indicates negative correlation between $\mathrm{Zn}$ content in muscle tissue and TL of fish: L. niloticus (Spearman's rank test, $r_{\mathrm{s}}=-0.317, p=0.032$ ) and $O$. niloticus (Spearman's rank test, $\left.r_{\mathrm{s}}=-0.453, p=0.045\right)$. Elsewhere, mean $\mathrm{Zn}$ values of $12.1 \mathrm{mg} / \mathrm{kg}$ and $10.3 \mathrm{mg} / \mathrm{kg}$ were recorded in the muscle tissue of $O$. niloticus and L. niloticus, respectively, from Lake Nasser (Mohamed 2008) - at least twofold lower than in our study. Very high concentrations were reported in muscle tissue of $O$. leucostictus $(604 \pm 82 \mathrm{mg} / \mathrm{kg} \mathrm{dw})$ from Lake Naivasha (Otachi et al. 2014) and for Hydrocynus forskahlii $(426 \pm 215 \mathrm{mg} / \mathrm{kg} \mathrm{dw})$ from Lake Turkana, Kenya (Plessl et al. 2017). Those studies attributed the high levels of $\mathrm{Zn}$ in fish muscle to elevated Cd levels, which block $\mathrm{Zn}$ containing enzymes, enhancing their expression. In liver tissue, $\mathrm{Zn}$ concentrations in L. niloticus $157 \pm 30 \mathrm{mg} / \mathrm{kg} \mathrm{dw}$ and mean concentrations in $O$. niloticus $(87.5-130 \mathrm{mg} / \mathrm{kg} \mathrm{dw})$ from our study were higher than the mean concentrations in O. leucostictus (73.1 mg/kg dw) (Otachi et al. 2014), in $O$. niloticus $(40.8 \mathrm{mg} / \mathrm{kg} \mathrm{dw}$ ) and in L. niloticus $(37.8 \mathrm{mg} / \mathrm{kg}$ dw) from Lake Nasser (Mohamed 2008).

\section{As}

Very few studies are available on As accumulation in freshwater invertebrates, and there are no records for $C$. nilotica, $P$. ovata, and M. bourguignati. The As concentrations in the invertebrates and fish were very low in this study. Arsenic has no known biological role, and accumulation in freshwater biota is mostly through direct uptake from water, generally only at environmentally elevated levels (Mcintyre and Linton 2012). In our study area, the concentrations were generally low in water $(1.47-1.89 \mu \mathrm{g} / \mathrm{l})$ and surface sediment (1.19-6.19 mg/kg dw) (Outa et al. 2019). This may help to explain the low levels in the fauna. The mean levels in C. nilotica from our study sites $(0.828-0.957 \mathrm{mg} / \mathrm{kg}$ $\mathrm{dw}$ ) were on the same magnitude with the findings of Tu et al. (2008) who recorded mean range concentrations of $0.41-1.46 \mathrm{mg} / \mathrm{kg} \mathrm{dw}$ in $M$. rosenbergii from the Mekong River Delta, Vietnam. The mean concentrations in molluscs at our study sites $(0.195-1.41 \mathrm{mg} / \mathrm{kg} \mathrm{dw})$ were lower than in the bivalve Unio pictorum from Lake Maggiore, Italy $(12 \mathrm{mg} / \mathrm{kg} \mathrm{dw}$; Ravera et al. 2003). The content in both $P$. ovata and $M$. bourguignati was below the maximum limits for human consumption $(0.5 \mathrm{mg} / \mathrm{kg} \mathrm{ww})$ given by the China Food and Drug Administration (CFDA 2014). In fish, As was not detected in any muscle samples (LOD $=0.02 \mathrm{mg}$ / $\mathrm{kg} \mathrm{dw}$ ). In fish liver tissue, it was detected in O. niloticus specimens from RS $(0.036 \pm 0.01 \mathrm{mg} / \mathrm{kg} \mathrm{dw})$, and the mean concentration in L. niloticus was $(0.043 \pm 0.01 \mathrm{mg} / \mathrm{kg})$. Our results agree in part with the findings of Machiwa (2003), who did not detect As $(\mathrm{LOD}=0.01 \mu \mathrm{g} / \mathrm{g} \mathrm{ww})$ in any liver and muscle samples of $O$. niloticus and $L$. niloticus from the Tanzanian side of Lake Victoria. In contrast, Ngure et al. (2014) recorded mean range values of $0.015-1.92 \mathrm{mg} / \mathrm{kg}$ As in whole samples of the silver cyprinid $R$. argentea from 
four sites in a gold mining region around Lake Victoria. This contrasting finding points to the possibility of interspecific and regional differences arising from anthropogenic impacts.

\section{$\mathrm{Ag}$}

$\mathrm{Ag}$ is accidentally taken up by aquatic animals through $\mathrm{Na}$ and/or $\mathrm{Cu}$ transport pathways, and animals from waters with low Ag levels can have substantial levels of Ag in their tissues, raising the question whether $\mathrm{Ag}$ could be a micronutrient (Wood 2012). There are no previous studies on the $\mathrm{Ag}$ levels in the fauna of Lake Victoria. The concentrations in $C$. nilotica and $P$. ovata foot and viscera varied significantly between the study sites (one-way ANOVA; $F$ (2, $69)=688.030, p<0.001, F(3,45)=9.425, p<0.0001$ and $F(3,45)=13.286, p<0.0001)$. As indicated in Fig. 2, levels in the invertebrates corresponded with surface sediment concentrations; $C$. nilotica and $P$. ovata are therefore potential indicators for $\mathrm{Ag}$ contamination. Like with $\mathrm{Cu}$ and $\mathrm{As}$, the levels in the foot and viscera of $P$. ovata did not differ significantly (Table 3). The translocation of Ag within the soft tissue of this snail is probably not restricted. Bioaccumulation was observed in the invertebrates, and the highest BAFs for $\mathrm{Ag}$ in the tissues in relation to the sediment were 15.2 for $P$. ovata foot, 11.7 for $P$. ovata viscera, and 5.56 for $C$. nilotica (SM Table 2). The concentrations in invertebrates were significantly positively correlated with $\mathrm{Cu}$ levels (Spearman's rank test, $r_{\mathrm{s}}=0.437, p<0.0001$ for C. nilotica; $r_{\mathrm{s}}=0.541$, $p=0.030$ for $M$. bourguignati; $r_{\mathrm{s}}=0.786, p<0.0001$ and for P. ovata). Our results therefore point to the potential common sources or intake paths and sequestration for $\mathrm{Cu}$ and $\mathrm{Ag}$ in the invertebrates. There is a paucity of data on the accumulation of $\mathrm{Ag}$ in invertebrates from natural waters. Experimental results, however, demonstrated that under Ag exposure some mollusks can accumulate high levels of $\mathrm{Ag}$ in their tissues. For instance, in an experiment where sediment was spiked with $\mathrm{AgNO}_{3}$ to $100 \mathrm{mg} / \mathrm{kg}$ up to $75 \mathrm{mg} / \mathrm{kg}$ $\mathrm{dw}, \mathrm{Ag}$ was recorded in the hepatopancreas of the viviparid snail Bellamya aeruginosa (Bao et al. 2018). This is much higher than recorded in the invertebrates from our study. In freshwater fish, Ag is rapidly taken up through the gills and intestine, and with low trophic transfer, biomagnification does not occur (Wood 2012). We recorded the highest concentrations in $O$. niloticus liver; the values varied between the study sites (Kruskal-Wallis test, $X^{2}(4)=37.232$, $p<0.0001$ ), with the highest concentrations in fish at the site impacted by Kisumu City (Fig. 2). Oreochromis niloticus liver is therefore a potential indicator for $\mathrm{Ag}$ contamination. At all sampling sites, the $O$. niloticus liver levels were higher than those in the corresponding surface sediment (Fig. 2; SM Table 2). Moreover, the liver levels were 20-119 times higher in $O$. niloticus than in L. niloticus. These higher values probably reflect dietary intake and habitat exposure. High concentrations of $\mathrm{Ag}$ have been reported in algae and zooplankton (Yoo-iam et al. 2014), which form a significant part of the $O$. niloticus diet. In addition, $O$. niloticus inhabits shallow inshore regions of the lake, where contact with contaminated surface sediment and alternative feeding on detritus may expose it to more Ag. Wood (2012) noted that $\mathrm{Ag}$ taken up by fish is sequestered by metallothionein, is well regulated in certain tissues, such as blood, gills, and white muscle by homeostatic mechanisms, and is accumulated in internal organs such as liver and kidney. This implies that beyond the differences in $\mathrm{Ag}$ exposure routes between the two fish species, Ag metabolism may differ as well. Homeostatic regulation in the muscle and accumulation in the liver and kidney might explain why $\mathrm{Ag}$ was not detected in fish muscle tissue. In the liver of $O$. niloticus, $\mathrm{Ag}$ concentrations were significantly positively correlated with $\mathrm{Cu}$ levels (Spearman's rank test, $r_{\mathrm{s}}=0.652, p<0.0001$ ).
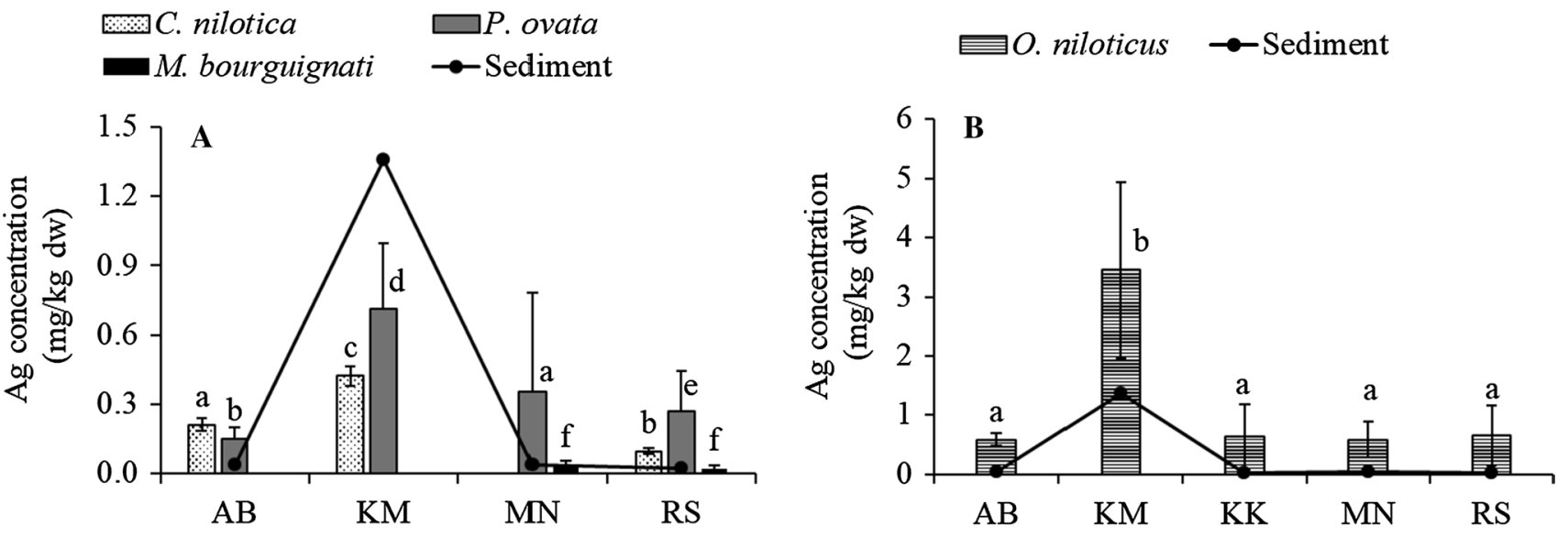

Fig. 2 Concentration patterns of Ag in C. nilotica, P. ovata viscera and M. bourguignati (a) and O. niloticus liver (b) in the current study and the corresponding surface sediment content in different sampling sites (Outa et al. 2019) 
This positive correlation is strongest at low concentrations of $\mathrm{Ag}$ (up to $1.5 \mathrm{mg} / \mathrm{kg} \mathrm{dw}$ ), after which the levels of $\mathrm{Cu}$ do not correspond with the rise in Ag levels (Fig. 3). The reasons for these differences are not known yet but certainly should draw attention for future research. Also, the levels of $\mathrm{Ni}$ in $O$. niloticus liver were positively correlated with $\mathrm{Ag}$ (Pearson's test, $r=0.479, p=0.033$ ). Ni uptake may involve proton-coupled divalent metal transporters with binding sites similar to those for $\mathrm{Cu}$ and sequestration into $\mathrm{Ni}$-induced metallothioneins (Pyle and Couture 2012). Our results therefore point to potential common sources or intake paths and sequestration for $\mathrm{Ni}, \mathrm{Cu}$, and $\mathrm{Ag}$ in $O$. niloticus. Studies on $\mathrm{Ag}$ accumulation in fish are sparse, with very few reports from Africa. Like in our study, no Ag was detected in the muscle tissue of fish from Lake Naivasha, Kenya (Plessl et al. 2017) and Vaal Dam, South Africa (Plessl et al. 2019). In fish liver, mean concentrations of $0.427 \pm 0.359 \mathrm{mg} / \mathrm{kg}$ $\mathrm{dw}$ in T. zillii from Lake Naivasha (Plessl et al. 2017) and $1.92 \pm 0.83 \mathrm{mg} / \mathrm{kg} \mathrm{dw}$ in L. umbratus from South Africa (Plessl et al. 2019) were reported. These values are higher than our L. niloticus liver levels $(0.032 \pm 0.02 \mathrm{mg} / \mathrm{kg} \mathrm{dw})$ but are in the same range as $O$. niloticus liver samples from $\mathrm{AB}$, $\mathrm{KK}, \mathrm{MN}$, and RS (Table 1). At KM, however, where the surface sediment was contaminated with $\mathrm{Ag}$, the liver concentrations in O. niloticus ranged from 1.03 to $6.90 \mathrm{mg} / \mathrm{kg} \mathrm{dw}$ with a mean value of $3.45 \mathrm{mg} / \mathrm{kg} \mathrm{dw}$, which is higher than in the above-mentioned studies from Lake Naivasha and Vaal Dam, clearly indicating that Ag pollution is reflected in fish liver. The consequences for the fish are still unknown, but we again underline the necessity of more closely examining the development in the distribution of $\mathrm{Ag}$ in the environment to avoid long term consequences for fish and other aquatic biota.

\section{Cd}

Aquatic invertebrates are net accumulators of nonessential elements, such as Cd (Abdennour et al. 2000; Rainbow 2007). Cd concentrations in C. nilotica samples from RS were significantly lower than those from $\mathrm{AB}$ and $\mathrm{KM}$ (Tukey HSD test, $p<0.001$ ). Mutela bourguignati from RS also had lower levels compared with MN (Mann-Whitney test, $U=13.0, p=0.046)$. Similarly, we recorded a spatial variation in $\mathrm{Cd}$ contents in $P$. ovata viscera (one-way ANOVA; $F(3,45)=10.8, p<0.001)$, with the samples from RS having significantly lower levels than elsewhere in the gulf (Table 3). The lower concentrations in the invertebrate samples from RS corresponded with the lower surface sediment values here; $C$. nilotica, $P$. ovata, and $M$. bourguignati are therefore potential bioindicators of $\mathrm{Cd}$ contamination. As indicated in SM (Table 2), the concentrations in P. ovata viscera and $M$. bourguignati were higher than the corresponding levels in the sediment. Cd concentrations in C. nilotica showed a strong positive correlation with $\mathrm{Cu}$ (Pearson's test, $r=0.809, p<0.0001$ ); this points to a common source and/ or intake path for these elements. Most of our findings on $\mathrm{Cd}$ levels in the invertebrates were not consistent with data from other studies. Mwamburi (2013) did not detect Cd (LOD not stated) in either $C$. nilotica or the bivalve Sphaerium sp. from Lake Victoria. In our study, $\mathrm{Cd}$ concentrations were: $0.046-0.069 \mathrm{mg} / \mathrm{kg} \mathrm{dw}$ in C. nilotica, 0.274 and $0.463 \mathrm{mg} /$ $\mathrm{kg} \mathrm{dw}$ in M. bourguignati, and $0.60-5.6 \mathrm{mg} / \mathrm{kg} \mathrm{dw}$ in $P$. ovata viscera. These concentrations, however, were lower than in invertebrates from polluted habitats elsewhere. For instance, $2.4-10.4 \mathrm{mg} / \mathrm{kg} \mathrm{dw}$ was recorded in the shrimp $A$. desmarestii in Algeria (Abdennour et al. 2000) and 5-29 mg/ $\mathrm{kg} d w$ in the viscera of Pomacea canaliculata in Fankou stream (China) (Deng et al. 2008). Regarding food safety for humans, the mean Cd content of $P$. ovata viscera from the $\mathrm{AB}$ sampling site $(1.11 \mathrm{mg} / \mathrm{kg}$ ww) surpassed the $1.0 \mathrm{mg} / \mathrm{kg}$ ww safety standard (EU 2008; FAO/WHO 2017), indicating a potential risk for consumption. In freshwater fish, $\mathrm{Cd}$ is taken up through gill exposure and is rapidly absorbed by various internal organs from the plasma, with the highest percent absorption occurring in the liver (Mcgeer et al. 2012). In our study, $O$. niloticus liver had higher levels than L. niloticus liver (Mann-Whitney test, $U=1052, p=0.015$ ). These higher levels in $O$. niloticus may result more from exposure and uptake via the gills from the habitat, namely contaminated shallow inshore areas. $\mathrm{Cd}$ has a long biological half-life in vertebrates (Mcgeer et al. 2012), and the levels in the sampling sites may reflect occasional or low-level chronic contamination. This might explain why the highest concentration in fish was recorded in $O$. niloticus liver at RS (Table 4), where Cd was lowest in the surface sediment, leading to a BAF of 2.79. A common source of Cd contamination is runoff from agricultural soils. $\mathrm{Cd}$ occurs in phosphate fertilizer to varying degrees and in agricultural soils where phosphate fertilizer is applied (Roberts 2014). In both fish species, no Cd was detected ( $\mathrm{LOD}=0.005 \mathrm{mg} / \mathrm{kg} \mathrm{dw}$ ) in muscle tissue. In liver tissue, there were significant negative correlations between $\mathrm{Cd}$ and $\mathrm{Pb}$ concentrations (Spearman's rank test, $r_{\mathrm{s}}=-0.337, p=0.007$ and $r_{\mathrm{s}}=-0.370, p=0.011$ for $O$. niloticus and L. niloticus, respectively. Contrary to the report by Çoğun et al. (2003), where Cd in O. niloticus tissues had no correlation with fish size, the values in $O$. niloticus liver were highly positively correlated with TL (Spearman's rank test, $\left.r_{\mathrm{s}}=0.798, p<0.01\right)$. In other studies, Otachi et al. (2014) reported mean concentrations of $0.74 \mathrm{mg} / \mathrm{kg} \mathrm{dw}$ in the muscle and $2.44 \mathrm{mg} / \mathrm{kg} \mathrm{dw}$ in the liver of $O$. leucostictus from Lake Naivasha. We recorded lower levels in fish tissue. Cd was below $0.005 \mathrm{mg} / \mathrm{kg} \mathrm{dw}$ in all muscle samples, and the highest mean concentration in liver tissue was $0.333 \pm 0.27 \mathrm{mg} / \mathrm{kg} \mathrm{dw}$. Based on the data from Otachi et al. (2014) and Outa et al. (2019), the concentrations in surface sediment in Lake Naivasha and Lake Victoria were of the 
same magnitude; hence, the different $\mathrm{Cd}$ contents in the fish can be attributed to site-specific physicochemical conditions and interspecific differences in Cd uptake and metabolism.

\section{$\mathrm{Pb}$}

$\mathrm{Pb}$ is a nonessential element whose net accumulation occurs in invertebrates (Abdennour et al. 2000; Rainbow 2007). Mutela bourguignati from RS had significantly lower levels of $\mathrm{Pb}$ compared with those from MN (Mann-Whitney test, $U=13.0, p=0.046)$. Similarly, the concentrations in $P$. ovata viscera varied significantly between the study sites (one-way ANOVA; $F(3,45)=4.087, p=0.012$ ), with the highest values at KM and the lowest at RS (Table 3). These variations corresponded to the $\mathrm{Pb}$ levels in the sediment (Fig. 4); accordingly, $M$. bourguignati and $P$. ovata viscera are potential indicators for $\mathrm{Pb}$ contamination. Our results on $\mathrm{Pb}$ in the invertebrates differ significantly from reports elsewhere. Abdennour et al. (2000) reported mean concentrations of $11.2-11.5 \mathrm{mg} / \mathrm{kg}$ in the atyid shrimp A. desmarestii in Algeria, which is higher than the mean concentrations $(4.38-4.71 \mathrm{mg} / \mathrm{kg} \mathrm{dw})$ that we recorded in C. nilotica. Likewise, concentrations in M. bourguignati $(0.73 \pm 0.97$ and $1.41 \pm 0.68 \mathrm{mg} / \mathrm{kg} \mathrm{dw}$ ) and in $P$. ovata viscera from our study sites $(0.48-15.5 \mathrm{mg} / \mathrm{kg} \mathrm{dw})$ were lower than the mean in Sphaerium sp. (31.8 mg/kg dw) from Lake Victoria (Mwamburi 2013). Morover, Deng et al. (2008) reported much higher levels in viscera of the snail Pomacea canaliculata $(160-620 \mathrm{mg} / \mathrm{kg} \mathrm{dw})$ in Fankou stream, which received effluent from a $\mathrm{Zn} / \mathrm{Pb}$ mine in southern China. Regarding the implications for human consumption, the $\mathrm{Pb}$ content of $P$. ovata viscera $(3.09 \pm 6.0 \mathrm{mg} / \mathrm{kg} \mathrm{ww})$ from the $\mathrm{KM}$ sampling site, surpassed the maximum limits of $1 \mathrm{mg} / \mathrm{kg}$ ww (EU 2008; FAO/WHO 2017), indicating a risk. In freshwater fish, $\mathrm{Pb}$ is taken up from the water into various tissues to varying degrees within and among populations and/or species (Mager 2012). In our study, except for two sites (MN and RS) where concentrations in $O$. niloticus liver were significantly lower (Table 4), Pb tissue concentrations did not show a clear preferential distribution between fish species or in
Fig. 3 Correlation between $\mathrm{Cu}$ and $\mathrm{Ag}$ concentrations in $O$. niloticus liver

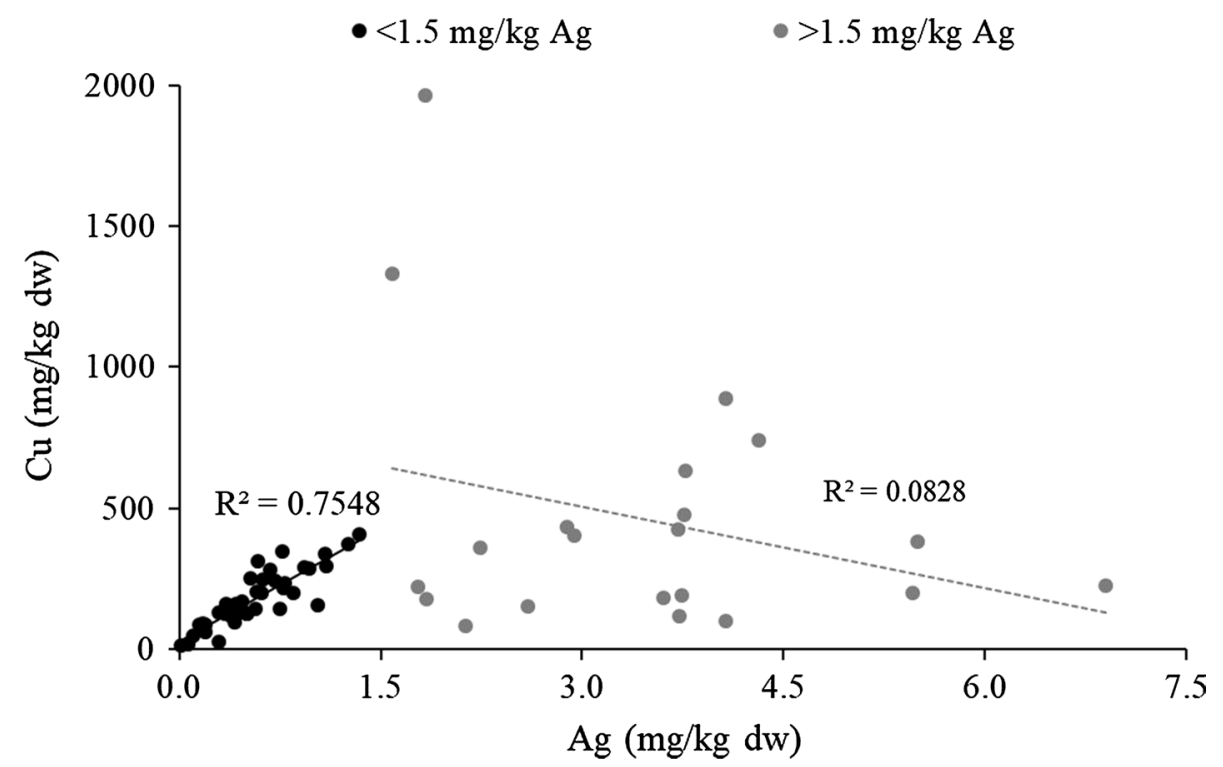

Fig. 4 Concentration patterns of $\mathrm{Pb}$ in C. nilotica, P. ovata viscera, and $M$. bourguignati in the current study and the corresponding surface sediment content in different sampling sites (data from Outa et al. 2019)

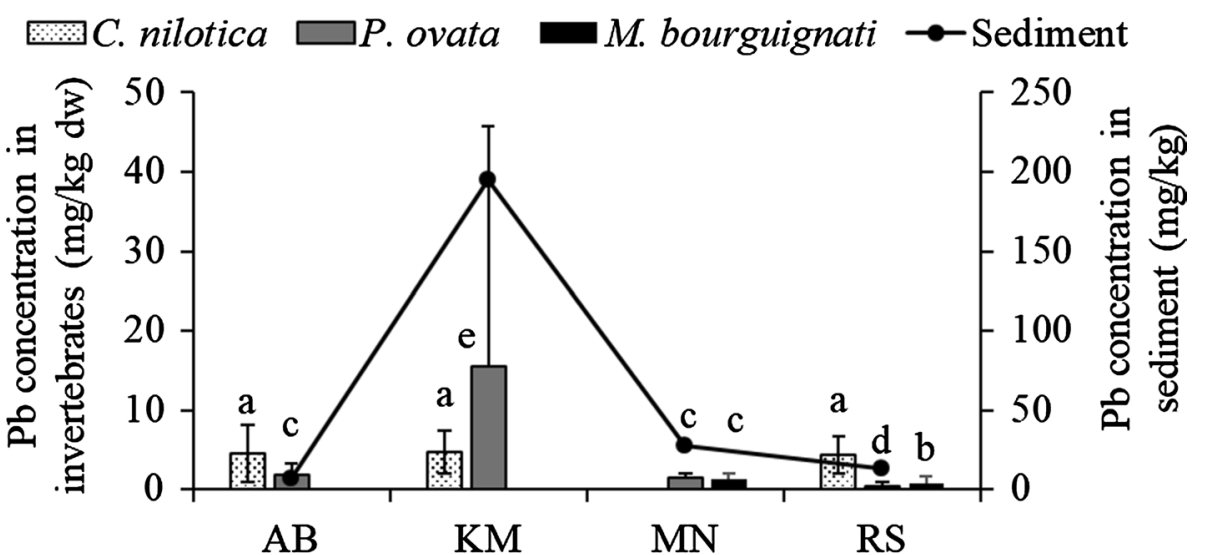


relation to sediment concentration. In both fish species, $\mathrm{Pb}$ concentrations were positively correlated with Ni levels in liver tissue (Spearman's rank test, $r_{\mathrm{s}}=0.336, p=0.007$ and Pearson's rank test, $r=0.686, p<0.0001$ for $O$. niloticus and L. niloticus, respectively). Similarly, $\mathrm{Pb}$ was positively correlated with $\mathrm{Zn}$ in $O$. niloticus liver (Spearman's rank test, $\left.r_{\mathrm{s}}=0.575, p=0.007\right)$ and $\mathrm{Cu}$ in L. niloticus muscle tissue (Spearman's rank test, $r_{\mathrm{s}}=0.339, p=0.020$ ). Fish size did not correlate to $\mathrm{Pb}$ concentrations in liver and muscle in our study, which agrees with the findings of Szarek-Gwiazda and Amirowicz (2006) and Luczynska et al. (2018). Elsewhere in the region, the mean $\mathrm{Pb}$ levels in the muscle and liver of $O$. niloticus and L. niloticus were at least three times higher than in the corresponding tissues of $O$. leucostictus from Lake Naivasha, where the levels of $\mathrm{Pb}$ in the sediment were also lower (Otachi et al. 2014). The levels in muscle tissue $(0.012-0.032 \mathrm{mg} / \mathrm{kg} \mathrm{ww})$ were, however, below the maximum acceptable limits for human consumption: $0.2 \mathrm{mg} / \mathrm{kg}$ ww (EU 2008) and $0.3 \mathrm{mg} / \mathrm{kg} \mathrm{ww} \mathrm{(FAO/WHO} \mathrm{2017)} \mathrm{and}$ therefore pose no risk for consumption.

\section{Conclusions}

The invertebrates in this study accumulated nearly all elements measured to higher levels than fish. The exceptions were $\mathrm{Cu}$ and $\mathrm{Ag}$, which were highest in $O$. niloticus liver. Contamination of the gulf with trace elements was best mirrored in the invertebrates, which accumulated $\mathrm{Cr}, \mathrm{Cd}, \mathrm{Ag}$, and $\mathrm{Pb}$ corresponding to their levels in the surface sediment. The accumulation in the two fish species and their bioindicative potential corresponded to their habitat characteristics and feeding behavior. The inshore-dwelling, omnivorous $O$. niloticus, which is exposed to higher contamination at the littoral areas of the lake, had significantly higher levels of most trace elements and showed a bioindicative potential for $\mathrm{Cu}$ and $\mathrm{Ag}$.

Our study shows strong positive correlations between the concentrations of $\mathrm{Cu}$ and $\mathrm{Ag}$ in the invertebrates and in $O$. niloticus in low $\mathrm{Ag}$ concentrations pointing to similar pathways for these elements. We also show a negative correlation between fish size and $\mathrm{Zn}$ concentrations in muscle and a positive correlation between $\mathrm{Cu}$ and $\mathrm{Cd}$ in $O$. niloticus liver. Regarding the health risk of consuming products from the lake, the levels of $\mathrm{Cr}, \mathrm{Ni}, \mathrm{Cu}, \mathrm{Zn}, \mathrm{Cd}$, and $\mathrm{Pb}$ in fish muscle do not pose a direct risk. On the other hand, there is potential health risk in relation to the $\mathrm{Zn}, \mathrm{Cd}$, and $\mathrm{Pb}$ contents of the gastropod $P$. ovata from Winam Gulf. Finally, given that $\mathrm{Cr}, \mathrm{Ni}$, and $\mathrm{Ag}$ are scarcely monitored in bioaccumulation investigations in African inland water bodies, the data serve as a basis for future investigations, especially for $\mathrm{Ag}$, whose levels were elevated in the liver of the omnivorous, inshoredwelling fish species.
Acknowledgements Open access funding provided by University of Vienna. The authors thank the Austrian Agency for International Cooperation in Education and Research (OeAD-GmbH) for funding parts of this study through a scholarship award within the Austrian Partnership Program in Higher Education and Research for Development (APPEAR). They also thank The National Council of Science and Technology, Kenya, for approval of this research through the Maseno University Ethics Review Committee: Reference Number - MSU/ DRPI/MUERC/00672/19. Finally, thanks to Maseno University, Kenya, for providing laboratory space, facilities, and technical assistance during data collection in Lake Victoria. Michael Stachowitsch is thanked for reviewing the English of this article.

Open Access This article is licensed under a Creative Commons Attribution 4.0 International License, which permits use, sharing, adaptation, distribution and reproduction in any medium or format, as long as you give appropriate credit to the original author(s) and the source, provide a link to the Creative Commons licence, and indicate if changes were made. The images or other third party material in this article are included in the article's Creative Commons licence, unless indicated otherwise in a credit line to the material. If material is not included in the article's Creative Commons licence and your intended use is not permitted by statutory regulation or exceeds the permitted use, you will need to obtain permission directly from the copyright holder. To view a copy of this licence, visit http://creativecommons.org/licenses/by/4.0/.

\section{References}

Abdennour C, Smith B, Boulakoud MS, Samraoui B, Rainbow P (2000) Trace metals in marine, brackish and freshwater prawns (Crustacea, Decapoda) from Northeast Algeria. Hydrobiologia 432:217-227. https://doi.org/10.1023/A:1004027204088

Bao S, Huang J, Liu X, Tang W, Fang T (2018) Tissue distribution of $\mathrm{Ag}$ and oxidative stress responses in the freshwater snail Bellamya aeruginosa exposed to sediment-associated Ag nanoparticles. Sci Total Environ 644:736-746. https://doi.org/10.1016/j. scitotenv.2018.07.011

Biney C et al (1994) Review of heavy metals in the African aquatic environment. Ecotoxicol Environ Saf 28:134-159. https://doi. org/10.1006/eesa.1994.1041

Budeba YL, Cowx IG (2007) The role of the freshwater shrimp Caridina nilotica (Roux) in the diet of the major commercial fish species in Lake Victoria, Tanzania. Aquat Ecosys Health Manag 10:368-380. https://doi.org/10.1080/14634980701703876

Bundi J et al (2013) Utilization of Caridina nilotica (Roux) meal as a protein ingredient in feeds for Nile tilapia (Oreochromis niloticus). Aquac Res 46(2):1-12. https://doi.org/10.1111/are.12181

Campbell L, Dixon DG, Hecky RE (2003) A review of mercury in Lake Victoria, East Africa: implications for human and ecosystem health. J Toxicol Environ Health Part B Crit Rev 6:325-356. https ://doi.org/10.1080/10937400306474

CFDA (2014) Maximum levels of contaminants in food. China national standard GB 2762-2012. People's Republic of China, Beijing

Chapman P (2016) Sediment contaminant bioaccumulation: with or without gut contents? Bull Environ Contam Toxicol 97(2):151152. https://doi.org/10.1007/s00128-016-1785-8

Chovanec A, Hofer R, Schiemer F (2003) Fish as bioindicators. In: Markert BA, Breuere AM, Zechmeister HG (eds) Bioindicators and biomonitors. Elsevier Science Ltd., Amsterdam. https://doi. org/10.1016/s0927-5215(03)80148-0

Coetzee L, du Preez H, Van Vuren J (2002) Metal concentrations in Clarias gariepinus and Labeo umbratus from the Olifants and 
Klein Olifants River, Mpumalanga, South Africa: zinc, copper, manganese, lead, chromium, nickel, aluminium and iron. Water SA 28:433-448. https://doi.org/10.4314/wsa.v28i4.4917

Çoğun HY, Yüzereroğlu TA, Kargın F (2003) Accumulation of copper and cadmium in small and large Nile tilapia Oreochromis niloticus. Bull Environ Contam Toxicol 71:1265-1271. https:// doi.org/10.1007/s00128-003-8523-8

Crul RCM (1995) Limnology and hydrology of Lake Victoria: comprehensive and comparative study of great lakes. Studies and Reports in Hydrology, vol 53. UNESCO, Paris

Deng PY, Shu WS, Lan CY, Liu W (2008) Metal contamination in the sediment, pondweed, and snails of a stream receiving effluent from a lead/zinc mine in southern China. Bull Environ Contam Toxicol 81:69-74. https://doi.org/10.1007/s0012 8-008-9428-3

Depledge MH, Weeks JM, Bjerregaard P (1998) Heavy metals. Handbook of ecotoxicology. Wiley, Oxford. https://doi. org/10.1002/9781444313512.ch27

Dudgeon D et al (2006) Freshwater biodiversity: importance, threats, status and conservation challenges. Biol Rev 81:163-182. https ://doi.org/10.1017/S1464793105006950

EU (2008) Commission regulation no. 629/2008 of 2 July 2008 amending regulation (EC) no. 1881/2006 setting maximum levels for certain contaminants in foodstuffs. European Union

Ezemonye L, Enobakhare V, Ilechie I (2006) Bioaccumulation of heavy metals $(\mathrm{Cu}, \mathrm{Zn}, \mathrm{Fe})$ in freshwater snail (Pila ovata; Oliver 1804) from Ikpoba River of Southern Nigeria. Afr J Aquat Sci 21:23-28. https://doi.org/10.4314/jas.v21i1.20057

FAO (2015) Fisheries and aquaculture-fishery and aquaculture country profiles-The Republic of Kenya. http://www.fao.org/ fishery/facp/KEN/en. Accessed 6 Jul 2019

FAO/WHO (2017) Joint FAO/WHO food standards programme codex committee on contaminants in food. 11th session. Working document for information and use in discussions related to contaminants and toxins in the GSCTFF. Rio de Janeiro, Brazil

Foxall C, Chale F, Bailey-Watts A, Patterson G, West K (2000) Pollution special study (PSS): pesticide and heavy metals in fish and molluscs of Lake Tanganyika. UNDP/GEF, Dar es Salaam

Fryer G (1960) The feeding mechanism of some atyid prawns of the genus Caridina. Trans R Soc Edinb 64:217-244

Games PA, Howell JF (1976) Pairwise multiple comparison procedures with unequal N's and/or variances: a Monte Carlo study. J Educ Stat 1:113-125. https://doi.org/10.2307/1164979

Gilbert BM, Hussain E, Jirsa F, Avenant-Oldewage A (2017) Evaluation of trace element and metal accumulation and edibility risk associated with consumption of Labeo umbratus from the Vaal Dam, South Africa. Int J Environ Res Public Health 14(678):115. https://doi.org/10.3390/ijerph14070678

Graf D, Cummings K (2006) Freshwater mussels (Mollusca: Bivalvia: Unionoida) of Angola, with description of a new species, Mutela wistarmorrisi. Proc Acad Natural Sci Phila 155:163194. https://doi.org/10.1635/i0097-3157-155-1-163.1

Grossel M (2012) Homeostasis and toxicology of essential metals. In: Wood C, Farrel A, Brauner C (eds) Fish physiology, vol 31A. Elsevier, Amsterdam, pp 53-133. https://doi.org/10.1016/ s1546-5098(11)31002-3

Gundacker C (2000) Comparison of heavy metal bioaccumulation in freshwater mollusks of urban river habitats in Vienna. Environ Pollut 110:61-71. https://doi.org/10.1016/S0269 -7491(99)00286-9

Hayes K et al (2015) Insights from an integrated view of the biology of apple snails (Caenogastropoda: Ampullariidae). Malacologia 58:245-302. https://doi.org/10.4002/040.058.0209

Heuzé V, Tran G (2017) Apple snail as animal feed. In: Joshi RC, Cowie RH, Sebastian LS (eds) Biology and management of invasive apple snails. Philipp Rice Res Inst, Muñoz, pp 369-385
Hogstrand C (2012) Homeostasis and toxicology of essential metals. In: Wood C, Farrell A, Brauner C (eds) Fish physiology, vol 31A. Elsevier, Amsterdam, pp 134-200

Kim H-Y (2015) Statistical notes for clinical researchers: post hoc multiple comparisons. Restor Dentist Endodon 40:172-176. https://doi.org/10.5395/rde.2015.40.2.172

Kishe-Machumu M, Machiwa J (2003) Distribution of heavy metals in sediments of Mwanza Gulf of Lake Victoria, Tanzania. Environ Int 28:619-625. https://doi.org/10.1016/S0160-4120(02)00099-5

Kitchell JF, Schindler DE, Ogutu-Ohwayo R, Reinthal PN (1997) The Nile perch in Lake Victoria: interactions between predation and fisheries. Ecol Appl 7:653-664. https://doi.org/10.2307/2269528

Lehman JT, Mbahinzireki GB, Mwebaza-Ndawula L (1996) Caridina nilotica in Lake Victoria: abundance, biomass, and diel vertical migration. Hydrobiologia 317(3):177-182. https://doi. org/10.1007/BF00036467

Luczynska J, Paszczyk B, Luczynski MJ (2018) Fish as a bioindicator of heavy metals pollution in aquatic ecosystem of Pluszne Lake, Poland, and risk assessment for consumer's health. Ecotoxicol Environ Saf 153:60-67. https://doi.org/10.1016/j.ecoen v.2018.01.057

Lung'ayia H, Sitoki L, Kenyanya M (2001) The nutrient enrichment of Lake Victoria (Kenyan waters). Hydrobiologia 458:75-82. https ://doi.org/10.1023/A:1013128027773

Macdonald D, Ingersoll CG, Berger TA (2000) Development and evaluation of consensus-based sediment quality guidelines for freshwater systems. Arch Environ Contam Toxicol 39:20-31. https:// doi.org/10.1007/s002440010075

Machiwa J (2003) Metal concentrations in sediment and fish of Lake Victoria near and away from catchments with gold mining acctivities. Tanzan J Sci 29:43-54. https://doi.org/10.4314/tjs.v29i2.18377

Mager EM (2012) Homeostasis and toxicology of non-essential metals. In: Wood C, Farrell A, Brauner C (eds) Fish physiology, vol 31B. Elsevier, Amsterdam, pp 185-236

Markert B, Fränzle S, Wünschmann S (2015) Chemical evolution: the biological system of the elements. Springer, Berlin. https://doi. org/10.1007/978-3-319-14355-2

Mbabazi J, Wasswa J (2010) Contamination by heavy metals in silver fish (Rastrineobola argentea) caught from Lakes Kyoga and Victoria, Uganda. Int J Environ Stud 67:543-556. https://doi. org/10.1080/00207233.2010.499000

Mcgeer C, Niyogi S, Smith D (2012) Homeostasis and toxicology of non-essential metals. In: Wood C, Farrell A, Brauner C (eds) Fish physiology, vol 31B. Elsevier, Amsterdam, pp 125-184

McGillicuddy E et al (2017) Silver nanoparticles in the environment: sources, detection and ecotoxicology. Sci Total Environ 575:231246. https://doi.org/10.1016/j.scitotenv.2016.10.041

Mcintyre DO, Linton TK (2012) Homeostasis and toxicology of nonessential metals. In: Wood C, Farrell A, Brauner C (eds) Fish physiology, vol 31B. Elsevier, Amsterdam, pp 297-350

Mohamed FAS (2008) Bioaccumulation of selected metals and histopathological alterations in tissues of Oreochromis niloticus and Lates niloticus from Lake Nasser, Egypt. Global Veterinaria 2(4):205-218

Mohd RN, Yap B (2011) Power comparisons of Shapiro-Wilk, Kolmogorov-Smirnov, Lilliefors and Anderson-Darling tests. J Stat Model Analyt 2:21-33

Mwamburi J (2013) Comparative spatial metal concentrations and partitioning in bottom sediments of two tropical freshwater lake basins, Kenya. Lakes Reserv Res Manag 18:329-355. https://doi. org/10.1111/lre.12040

Ngure V, Davies T, Kinuthia G, Sitati N, Shisia S, Oyoo-Okoth E (2014) Concentration levels of potentially harmful elements from gold mining in Lake Victoria region, Kenya: environmental and health implications. J Geochem Explor 144:511-516. https://doi. org/10.1016/j.gexplo.2014.04.004 
Njiru M, Okeyo-Owuor JB, Muchiri M, Cowx IG (2004) Shifts in the food of Nile tilapia, Oreochromis niloticus (L.) in Lake Victoria, Kenya. Afr J Ecol 42:163-170. https://doi.org/10.111 1/j.1365-2028.2004.00503.x

Njuru P, Hecky RE (2005) Nutrient concentrations in Nyanza Gulf, Lake Victoria, Kenya: light limits algal demand and abundance. Hydrobiologia 534:131-140. https://doi.org/10.1007/s1075 0-004-1418-9

Njuru P, Hecky RE, Guildford SJ, Macintyre S (2013) Spatial variability of nutrient concentrations, fluxes, and ecosystem metabolism in Nyanza Gulf and Rusinga Channel, Lake Victoria (East Africa). Limnol Oceanogr 58:774-789. https://doi.org/10.4319/ 10.2013.58.3.0774

Ochieng E, Lalah J, Wandiga S (2006) Heavy metals in water and surface sediments in Winam Gulf of Lake Victoria, Kenya. Bull Environ Contam Toxicol 77:459-468. https://doi.org/10.1007/ s00128-006-1087-7

Okungu JO, Njoka S, Abuodha JOZ, Hecky RE (2005) An introduction to Lake Victoria catchment, water quality, physical limnology and ecosystem status (Kenyan sector). In: Abuodha JOZ, Hecky RE (eds) Lake Victoria environment report water quality and ecosystem status: Kenya national water quality synthesis report. Lake Victoria Environment Management Project (LVEMP), Kisumu, pp 1-27

Ongeri DMK, Lalah JO, Wandiga SO, Schramm K-W, Michalke B (2012) Seasonal variability in cadmium, lead, copper, zinc and iron concentrations in the three major fish species, Oreochromis niloticus, Lates niloticus and Rastrineobola argentea in Winam Gulf, Lake Victoria: impact of wash-off into the Lake. Bull Environ Contam Toxicol 88:166-171. https://doi.org/10.1007/s0012 8-011-0472-z

Otachi E, Körner W, Avenant-Oldewage A, Fellner-Frank C, Jirsa F (2014) Trace elements in sediments, blue spotted tilapia Oreochromis leucostictus (Trewavas, 1933) and its parasite Contracaecum multipapillatum from Lake Naivasha, Kenya, including a comprehensive health risk analysis. Environ Sci Pollut Res Int 21:7339-7349. https://doi.org/10.1007/s11356-014-2602-8

Outa JO, Kowenje CO, Plessl C, Jirsa F (2019) Distribution of arsenic, silver, cadmium, lead and other trace elements in water, sediment and macrophytes in the Kenyan part of Lake Victoria: spatial, temporal and bioindicative aspects. Environ Sci Pollut Res. https ://doi.org/10.1007/s11356-019-06525-9

Parmar KT, Rawtani D, Agrawal Y (2016) Bioindicators: the natural indicator of environmental pollution. Front Life Sci 9:1-9. https ://doi.org/10.1080/21553769.2016.1162753

Peña SC (2017) Accumulation of copper and other elements by the apple snail Pomacea canaliculata. In: Joshi RC, Cowie RH, Sebastian LS (eds) Biology and management of invasive apple snails. Philippine Rice Research Institute, Muñoz, pp 133-144

Plessl C, Otachi E, Körner W, Avenant-Oldewage A, Jirsa F (2017) Fish as bioindicators for trace element pollution from two contrasting lakes in the eastern Rift Valley, Kenya: spatial and temporal aspects. Environ Sci Pollut Res 24:1-10. https://doi.org/10.1007/ s11356-017-9518-Z

Plessl C, Gilbert B, Sigmund MF, Theiner S, Avenant-Oldewage A, Keppler B, Jirsa F (2019) Mercury, silver, selenium and other trace elements in three cyprinid fish species from the Vaal Dam, South Africa, including implications for fish consumers. Sci Total Environ 659:1158-1167. https://doi.org/10.1016/j.scito tenv.2018.12.442

Pure Earth and Green Cross (2016) World's worst pollution problems 2016: the toxins beneath our feet. NY USA, Zurich Switzerland, pp 1-56

Pyle G, Couture P (2012) Homeostasis and toxicology of essential metals. In: Wood C, Farrell A, Brauner C (eds) Fish physiology, vol 31A. Elsevier, Amsterdam, pp 253-290
Rainbow PS (2007) Trace metal bioaccumulation: models, metabolic availability and toxicity. Environ Int 33:576-582. https://doi. org/10.1016/j.envint.2006.05.007

Ravera O, Cenci R, Beone GM, Dantas M, Lodigiani P (2003) Trace element concentrations in freshwater mussels and macrophytes as related to those in their environment. J Limnol 62:61-70. https:// doi.org/10.4081/jlimnol.2003.61

Reid SD (2012) Homeostasis and toxicology of essential metals. In: Wood C, Farrell A, Brauner C (eds) Fish physiology, vol 31A. Elsevier, Amsterdam, pp 375-416

Roberts TL (2014) Cadmium and phosphorous fertilizers: the issues and the science. Proc Eng 83:52-59. https://doi.org/10.1016/j. proeng.2014.09.012

Szarek-Gwiazda E, Amirowicz A (2006) Bioaccumulation of trace elements in roach, silver bream, rudd, and perch living in an inundated opencast sulphur mine. Aquat Ecol 40:221-236. https://doi. org/10.1007/s 10452-004-7341-3

Tchounwou PB, Yedjou CG, Patlolla AK, Sutton DJ (2012) Environmental toxicology. In: Luch A (ed) Molecular, clinical and environmental toxicology, Experientia Supplementum, vol 3. Springer, Basel, pp 133-164. https://doi.org/10.1007/978-3-7643-8340-4_6

Tu NPC, Ha NN, Ikemoto T, Tuyen BC, Tanabe S, Takeuchi I (2008) Bioaccumulation and distribution of trace elements in tissues of giant river prawn Macrobrachium rosenbergii (Decapoda: Palaemonidae) from South Vietnam. Fish Sci 74:109-119. https://doi. org/10.1111/j.1444-2906.2007.01474.x

USEPA (2018a) Regional screening levels (RSLs)-user's guide 2018. https://www.epa.gov/risk/regional-screening-levels-rsls-users -guide. Accessed $19 \mathrm{Feb} 2019$

USEPA (2018b) Regional screening levels (RSLs)-equations 2018. https://www.epa.gov/risk/regional-screening-levels-rsls-equat ions. Accessed 19 Feb 2019

USEPA (2018c) Regional screening levels (RSLs)-generic tables 2018. https://www.epa.gov/risk/regional-screening-levels-rsls-generictables. Accessed 19 Feb 2019

Van Damme D (2017) Pila ovata (amended version of 2016 assessment). The IUCN red list of threatened species 2017: e. T165765A110769691. http://dx.doi.org/10.2305/IUCN. UK.2017-1.RLTS.T165765A110769691.en. Downloaded on 26 Aug 2019

Walpole S, Prieto-Merino D, Edwards P, Cleland J, Stevens G, Roberts I (2012) The weight of nations: an estimation of adult human biomass. BMC Public Health 12:439. https://doi. org/10.1186/1471-2458-12-439

WHO (2002) Silver and silver compounds: environmental aspects. World Health Organisation, Geneva

Wood C (2012) Homeostasis and toxicology of non-essential metals. In: Wood C, Farrel A, Brauner C (eds) Fish physiology, vol 31B. Elsevier, Amsterdam, pp 1-65

Yap CK, Ismail A, Tan SG (2004) Heavy metal (Cd, Cu, Pb and Zn) concentrations in the green-lipped mussel Perna viridis (Linnaeus) collected from some wild and aquacultural sites in the west coast of Peninsular Malaysia. Food Chem 84(4):569-575. https://doi.org/10.1016/S0308-8146(03)00280-2

Yoo-iam M, Chaichana R, Satapanajaru T (2014) Toxicity, bioaccumulation and biomagnification of silver nanoparticles in green algae (Chlorella sp.), water flea (Moina macrocopa), blood worm (Chironomus spp.) and silver barb (Barbonymus gonionotus). Chem Speciat Bioavail 26:257-265. https://doi.org/10.3184/09542 2914X14144332205573

Zhou Q, Zhang J, Fu J, Shi J, Jiang G (2008) Biomonitoring: an appealing tool for assessment of metal pollution in the aquatic ecosystem. Anal Chim Acta 606:135-150. https://doi.org/10.1016/j. aca.2007.11.018 